\title{
82. NEOGENE KINEMATICS IN THE JAPAN SEA REGION AND VOLCANIC ACTIVITY OF THE NORTHEAST JAPAN ARC ${ }^{1}$
}

\author{
Laurent Jolivet ${ }^{2}$ and Kensaku Tamaki ${ }^{3}$
}

\begin{abstract}
Deep sea drilling in the Japan Sea during ODP Legs 127 and 128 brought new constraints to the timing and dynamics of backarc opening. The nature and age of the oceanic basement as well as the recovered lithology allow us to present new reconstructions from $25 \mathrm{Ma}$ to the present. On-land deformation data as well as the offshore crustal structure and timing of volcanic events are the major constraints we use. The Japan Sea opened as a complex pull-apart basin in a dextral shear zone that extends more than $2000 \mathrm{~km}$ from Central Japan to Northern Sakhalin. Oceanic crust was emplaced in the northern part of the Japan Basin, and highly extended arc crust in the Tsushima and Yamato basins. Westward propagation of oceanic spreading was active in the early Miocene. Our reconstructions give a minimum estimate for the finite dextral displacement of about $400 \mathrm{~km}$. We observe correlations between volcanic events and tectonic phases, and we explore the hypothesis that variations in the character of volcanism during the Neogene in Northeast Japan can be due to changes in the tectonic status of the arc crust other than deep-seated variations in the mantle: (1) starvation of the volcanic activity in the late Miocene (10-7 Ma) is correlated with a reorganization of the stress field over the whole region from a dextral transtensional field during the Japan Sea opening to the present compressional field, and this period of inversion did not allow the ascent of magma through the upper brittle crust; (2) correlation is also seen between the formation of the incipient subduction zone at $1.8 \mathrm{Ma}$ along the eastern margin of the Japan Sea and the transition from acidic to andesitic volcanism in Northeast Japan. Compression between 7 and $2 \mathrm{Ma}$ is associated with the formation of large calderas and eruptions of acidic products, after which the present-day andesitic volcanism began at $2 \mathrm{Ma}$. During the compressive period the magma could not easily make its way up to the surface and stayed longer in the deep crust, where it could differentiate until the formation of a caldera. After localization of strain along the eastern margin of the Japan Sea and inception of the new subduction zone, which partly released the stress across the arc, the ascent of magma became much easier and the character of surface eruptions thus changed to less explosive. We also discuss the migration of the volcanic front through time from $30 \mathrm{Ma}$ to the present with respect to tectonic processes.
\end{abstract}

\section{INTRODUCTION}

Western Pacific marginal basins opened during the Tertiary, with the largest of them (Japan Sea, Shikoku-Parece Vela Basin, and South China Sea) during the late Oligocene to the middle Miocene. The opening of these large basins, which are now extinct or in the process of closure, is symptomatic of tensional conditions along the eastern margin of Asia during the same period. Reconstructing their opening geometry is important from two points of view. First, it can be a way of testing ideas on opening because a given geometry is related with the thermal or sedimentological evolution of a basin. It can then be used to assess stress and strain boundary conditions that evolved with time during intracontinental deformation and block extrusion in Asia and thus to refine mechanical models of continental collision and its consequences.

The Japan Sea (Fig. 1) opened during the early and middle Miocene and a slow convergence began recently along the eastern margin (Fukao and Furumoto, 1975; Nakamura, 1983; Tamaki and Honza, 1985). The basin has thus already begun the second half of its life and is about to disappear by subduction. It thus offers the possibility for studying both the opening and closing mechanisms, because the fairly recent inception of subduction left the structures contemporaneous with opening almost undeformed.

Based on the results of ODP Legs 127 and 128 (Fig. 2), as well as on-land field studies, we propose geometric reconstructions of the opening and incipient closing of Japan Sea from 25 Ma to the present. The drilling results constrain (1) the age of oceanic crust, (2) the rates of subsidence vs. time at various sites, (3) the age of inception of

\footnotetext{
'Tamaki, K., Suyehiro, K., Allan, J., McWilliams, M., et al., 1992. Proc. ODP, Sci. Results, 127/128, Pt. 2: College Station, TX (Ocean Drilling Program).

${ }^{2}$ Département de Géologie, Ecole normale supérieure, 24 rue Lhomond, 75231 Paris cedex 05. France.

${ }^{3}$ Ocean Research Institute, University of Tokyo, 1-15-1 Minami Dai, Nakano Ku, Tokyo, Japan.
}

active convergence along the eastern margin, and (4) the timing of volcanic activity of the arc. Based principally on the frequency of ash layers in the cores recovered during Legs 127 and 128 (Fig. 2) we see correlations between tectonic stages and volcanic events at arc scale. We explore then the hypothesis that variations in the character of Neogene volcanism in Northeast Japan can be due to changes in the tectonic status of the arc crust rather than deep-seated variations in the mantle.

Our research in the Japan Sea was until recently focused mainly on the apparent contradiction between the on-land paleomagnetic data, which imply a very fast opening with rotation of Southwest Japan (Otofuji et al., 1985), and on other studies, including ours, which instead show a longer time span, considerable strike-slip motion, and a pull-apart geometry (Lallemand and Jolivet, 1985; Kimura and Tamaki, 1986). This contradiction was partly solved with more sophisticated models that integrated the demonstrated rotations in the framework of a strike-slip shear zone (Jolivet et al., 1991). But the contradiction on the timing remained unsolved until the results of ODP drilling in the Yamato and Japan basins. We are now able to describe the tectonic evolution of the Japan Sea in terms of opening kinematics and of volcanic activity.

\section{GEOMETRICAL CONSTRAINTS}

The geometry of our reconstructions is constrained by (1) the internal bathymetric features and crustal structures of the Japan Sea derived from geophysical studies (Tamaki, 1988), and (2) the deformation mechanism along the eastern margin of the Japan Sea (Jolivet et al., 1991) based on field data and small-scale physical modeling.

\section{Crustal Structure}

The Japan Sea is divided into three major deep basins: Japan, Yamato, and Tsushima basins (Fig. 1). The crustal structure in the 


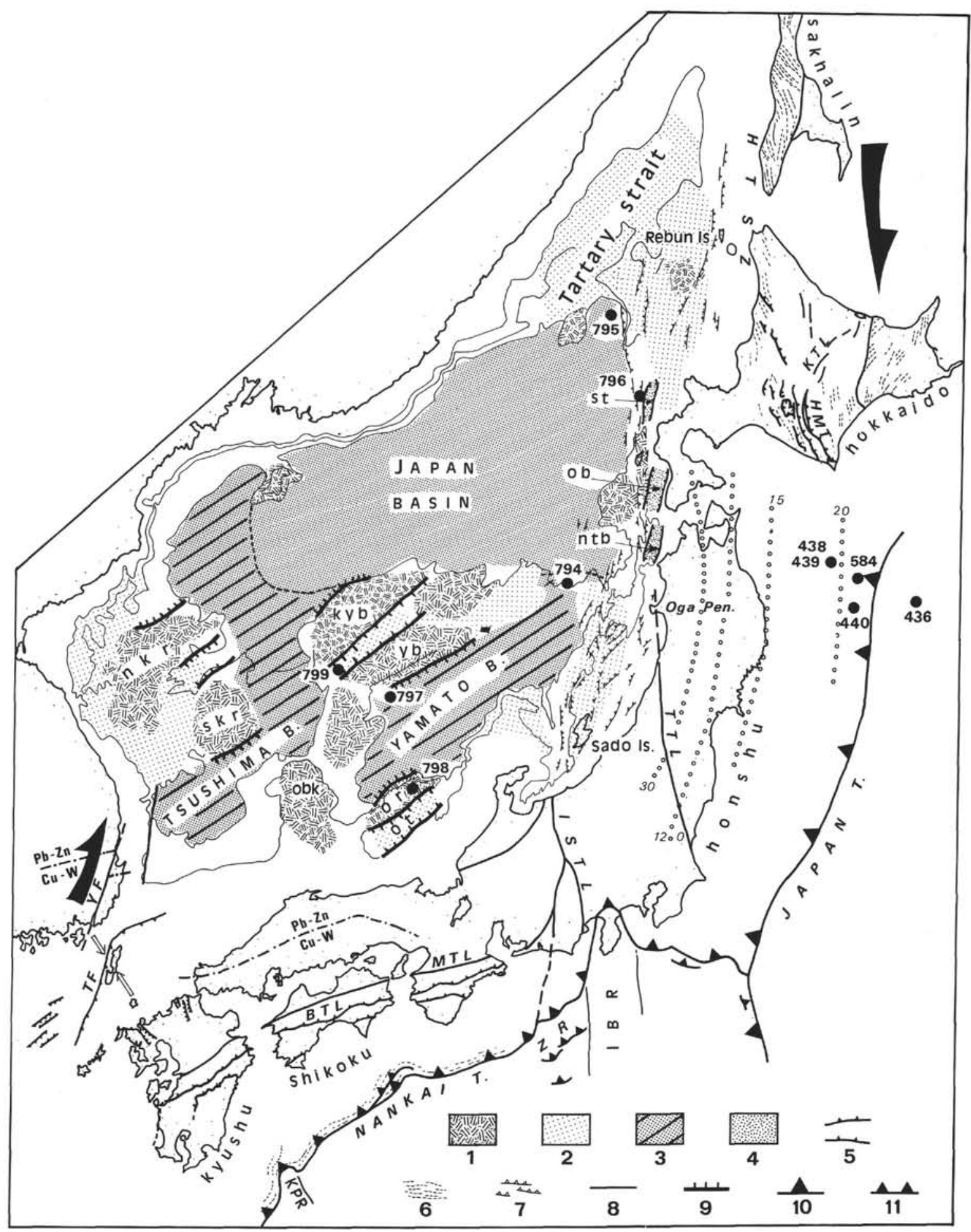

Figure 1. Tectonic map of the Japan Sea region showing the distribution of oceanic crust (dark) and continental blocks identified by Tamaki (1988), modified after Jolivet et al. (1991). Sites 794 through 799 of Legs 127 and 128 are shown as well as Sites 436, 438, 440, and 584 of previous DSDP legs. The position of the volcanic front at different periods is shown after Tatsumi et al. (1989) and Ohguchi et al. (1989). Ages (Ma) of the volcanic front are indicated. BTL $=$ Butsuzo Tectonic Line, HMT = Hidaka Main Thrust, HTSZ = Hidaka Tartary Shear Zone (Lallemand and Jolivet, 1985), IBR = Izu-Bonin Ridge, ISTL = Itoigawa-Shizuoka Tectonic Line, KPR = Kyushu-Palau Ridge, KTL = Kamishiyubetsu Tectonic Line (Kimura et al., 1983), kyb = Kita Yamato Bank, MTL = Median Tectonic Line, nkr = North Korean Ridge, ntb $=$ Nishi-Tsugaru Basin, obk = Oki Bank, ob = Okushiri Basin, or $=$ Oki Ridge, ot $=$ Oki Trough, TF $=$ Tsushima Fault, TTL = Tanakura Tectonic Line, skr = South Korean Ridge, st = Shiribeshi Trough, $y b=$ Yamato Bank, YF = Yangsan Fault, ZR = Zenisu Ridge. Pb-Zn and Cu-W represent the metallogenic belts offset by the Yangsan and Tsushima faults described in Sillitoe (1977). (1) continental crust, (2) thinned continental crust, (3) oceanic crust and extremely thinned continental crust (ruled), (4) Miocene en-echelon grabens, (5) on-land thrusts, (6) fold axes, (7) active offshore thrusts, (8) strike-slip faults, (9) normal faults, (10) Pacific plate subduction trench, (11) Philippine Sea plate subduction trench. 


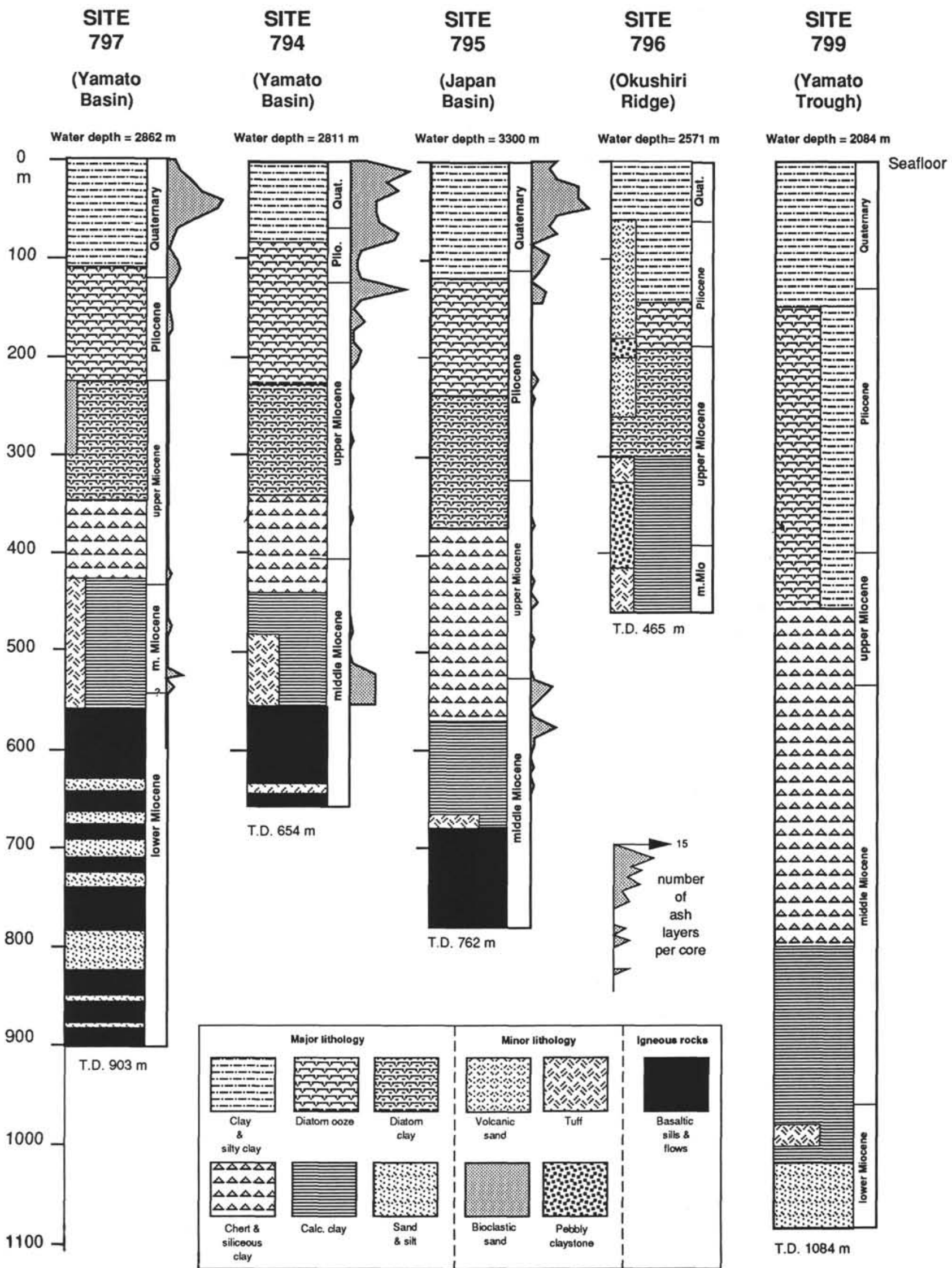

Figure 2. Lithologic correlation among five sites drilled during Leg 127, after Tamaki, Pisciotto, Allan, et al. (1990) and Ingle, Suyehiro, von Breymann, et al. (1990). The number of ash layers per core is shown on the right sides of the columns for Sites 794, 795, and 797. 
Japan Basin is identical to that of a normal oceanic crust overlain by 2000 to $3000 \mathrm{~m}$ of sediments. According to Ludwig et al. (1975), the thickness of the crust without the sedimentary cover is $6-7 \mathrm{~km}$. The velocity structure also is similar to that of a normal oceanic crust. In contrast, the crust in the Yamato Basin is twice as thick, while the velocity structure is that of a normal oceanic crust with double the thickness for each layer (Hirata et al., 1987; Katao, 1988).

Two models are possible in a first approach for the origin of the thick crust in the Yamato Basin. It can first be due to an Iceland-like mantle plume, where an anomalously large magma chamber at the spreading center causes a thicker oceanic crust (Hirata et al., 1989). The second model is that of an extended island arc crust. In our reconstructions we adopt the latter model for the following reasons: (1) no magnetic anomalies are observed in the Yamato Basin, which implies the absence of a spreading center; and (2) the heat flow in the Yamato Basin is exactly as expected, given the age of the lithosphere (Tamaki, Pisciotto, Allan, et al., 1990), which does not support anomalous heat production caused by a mantle plume during the opening.

There are no good data concerning the full crustal structure of the Tsushima Basin. Ludwig et al. (1975) reported that none of the results of three sonobuoy stations in the Tsushima Basin detected the refraction signal from the Moho, suggesting a rather thick crust. The basement depth is $2 \mathrm{~km}$ shallower than that of the Japan Basin according to their seismic-refraction results. Based on these observations we also assume here a thinned continental crust analogous to that of the Yamato Basin. The westernmost part of the Japan Basin is also floored by thinned continental crust because its basement depth is shallow (Gnibidenko, 1979).

Magnetic anomalies are poorly defined in the Japan Sea as compared to other backarc basins in the Western Pacific. Tamaki and Kobayashi (1988), however, recently proposed a tentative identification of the magnetic anomalies in the eastern part of the Japan Basin based on a detailed survey. Anomalies $7 \mathrm{~A}$ ( $27 \mathrm{Ma}$ ) to $5 \mathrm{E}$ (19 Ma) with a $\mathrm{N} 70^{\circ} \mathrm{E}$ trend were suggested by them (Tamaki, Pisciotto, Allan, et al., 1990). These anomalies imply an early Miocene opening for the Japan Basin. They recognized a fossil spreading center with the same trend and with a possible southwestward propagation.

Isezaki and Uyeda (1973) noted linear magnetic anomalies with an east-northeast trend north of the Yamato Rise, based on a compilation of all data available at that time. This observation suggests that the western part of the Japan Basin also has a history of seafloor spreading. Magnetic anomalies were not clearly identified either in the Yamato Basin or in the Tsushima Basin. The age of opening of the Yamato and Tsushima basins was constrained until recently only by heat-flow data that also suggested an early to middle Miocene age (Tamaki, 1986). These dates were in conflict with those based on the interpretation of paleomagnetic data acquired in on-land sedimentary sections (Otofuji et al., 1985), which suggested instead a very fast opening at about $15 \mathrm{Ma}$.

\section{Strike-Slip Shear along the Eastern Margin}

Jolivet and Miyashita (1985) and Jolivet and Huchon (1989) described the high-temperature ductile deformation of the Hidaka Shear Zone, which runs north-south across Hokkaido and was active during the late Oligocene to middle Miocene as a dextral shear zone (Figs. 1 and 3). A study of brittle structures was then completed along the entire eastern margin from Rebun Island in the north to Noto Peninsula and Yatsuo Basin in the south (Jolivet et al., 1991; M. Fournier, unpub. data). The results confirm that the entire eastern margin during the early and middle Miocene was a right-lateral strike-slip shear zone with an evolution from transpression in the north (Hidaka Shear Zone) to transtension in the south. Kimura and Tamaki (1986) also assigned dextral strike-slip movement along Central Hokkaido and Sakhalin from the Oligocene to the middle Miocene. In the Hidaka Shear Zone the major structures are a dextral ductile-shear zone with high-temperature deformation, and north-

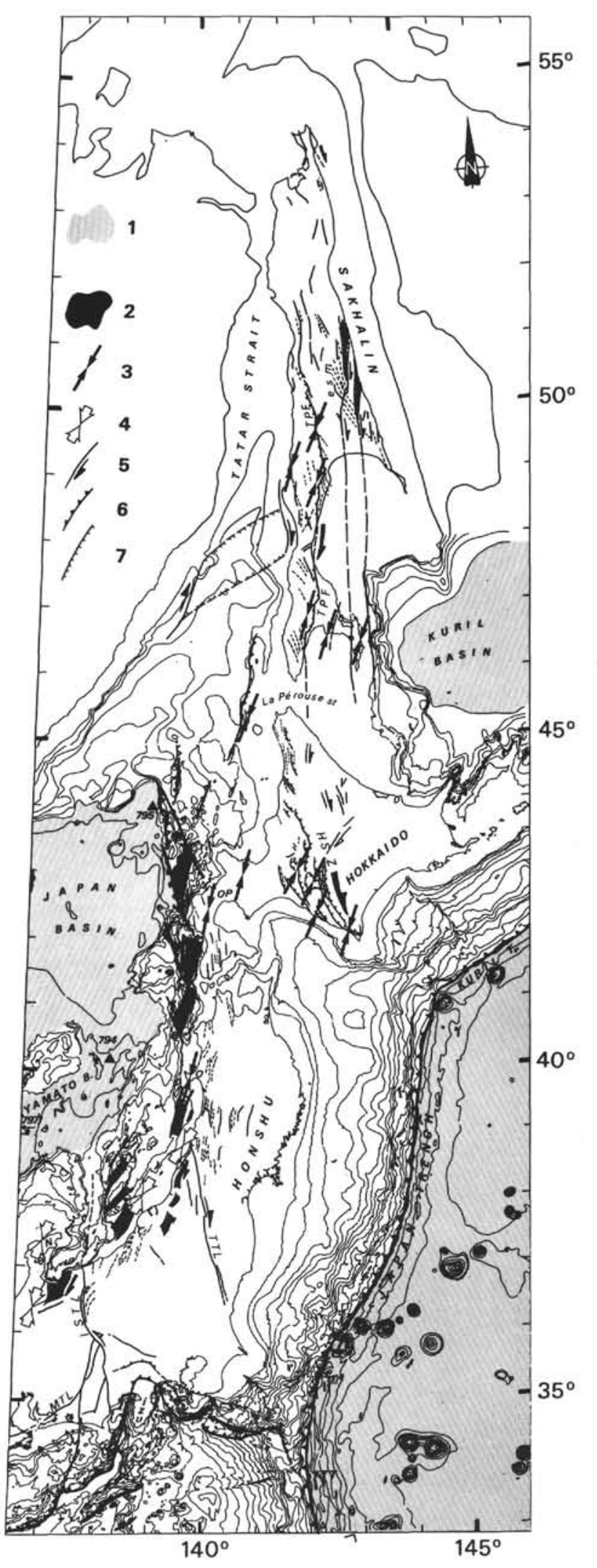

Figure 3. Tectonic map of the dextral strike-slip shear zone from Central Japan to Northern Sakhalin. Key shows (1) oceanic crust, (2) Miocene filling of en-echelon grabens, (3) direction of $\sigma_{1}$ in the early to middle Miocene, (4) direction of $\sigma_{2}$ in the early to middle Miocene, (5) strike-slip faults, (6) thrust faults, and (7) normal faults. Dashed lines are fold axes. 
west-trending en-echelon folds and thrusts in the Cenozoic deposits. Along the eastern margin major structures are en-echelon northeasttrending narrow grabens separated by northwest-trending dextral transfer faults (Fig. 3). Fault-set analysis following Angelier's (1984) method reveals that from north to south the maximum horizontal compression everywhere trends northeast (Fig. 3), although it changes from maximum compression $\sigma_{1}$ in the north to intermediate compression $\sigma_{2}$ in the south, illustrating the transition from transpression to transtension. After the middle Miocene all structures are compatible with an east-west horizontal compression and with active convergence. Recent uplift of the Hidaka Shear Zone and folding of the Cenozoic deposits along the eastern margin, as well as fast subsidence and formation of compressional structures in the en-echelon basins initially formed during the extensional period, are related to this recent stage.

Following Kimura et al. (1983), our survey begins in Sakhalin Island along the northern extension of this shear zone (Fig. 3). The Hidaka Shear Zone extends through Central Sakhalin, where the most prominent structure is the Tym-Poronaisk Fault, which can be followed for more than $600 \mathrm{~km}$. Rozhdestvenskiy $(1982,1986)$ described it as a dextral strike-slip fault as well as minor parallel north-south faults in the East Sakhalin Mountains. Based on a field survey along several sections across the Tym-Poronaisk Fault and East Sakhalin Mountains, as well as a study of Landsat and Spot images (M. Fournier, unpub. data), we confirm this interpretation and propose the tectonic map shown in Figure 3. The major features in favor of dextral motion are the following: (1) en-echelon northwest-trending folds in the western half of Sakhalin in the Cretaceous and Cenozoic deposits, and (2) north- to north-northeast-trending enechelon elongated Miocene basins associated with north-south faults in the East Sakhalin Mountains. From the northernmost part of the island (Schmidt Peninsula) Rozdestvenskiy $(1982,1986)$ describes dextral offset along north-south-trending faults. Recent sediments (Pliocene and Quaternary) are apparently not affected by this dextral shear and show only tilting. However, some focal mechanisms of earthquakes (L. S. Oscorbin, unpub. data) close to the Tym-Poronaisk Fault show active dextral displacement. This and the fact that the east-west compression that is so clear in the south along Hokkaido and Honshu is not clearly recorded here lead us to think that dextral motion is still active in Sakhalin, although most likely at much slower rates.

The synthesis of these observations leads us to infer the presence of a 2000-km-long dextral shear zone along the eastern margin of the Japan Sea from Yatsuo Basin (south of Noto Peninsula, Fig. 3) to northern Sakhalin. This major feature was active during the opening of the Japan Sea and implies a large north-south component for the displacement of Japan relative to Asia. As stated earlier in Lallemand and Jolivet (1985) and Jolivet et al. (1991), this north-south motion is accommodated by dextral motion along the Yangsan and Tsushima north-south-trending faults between South Korea and Japan (Fig. 1). Sillitoe (1977) had described and quantified the dextral offset across these faults to $200 \mathrm{~km}$. There had thus been a southward drift of Central and Southwest Japan during the Japan Sea opening between two north-south dextral master faults, which is the geometry of a pull-apart basin of unusually large extent. The motion of Northeast Japan relative to Asia can be further constrained by the observation that the transfer faults that separate the en-echelon grabens have a changing orientation from north to south and fit very well in small circles about a pole located west of Korea (Fig. 4) (Jolivet et al., 1991). This is the pole we shall use in our reconstructions, thus assuming that these faults are purely dextral faults.

In this paper we use the Tsushima and Yangsan faults as master dextral faults that guide the pull-apart opening of the Japan Sea, but there are evidences on Tsushima Island of sinistral motion at sometime during the Tertiary. The age of the deformed sediments and of the sinistral shear is disputed, however. The deformation postdates the age of the sediments, which is not well established. Based on fission-track dating, late Oligocene to early Miocene ages were found (Takahashi and Hayashi, 1985). More recently, based on foraminifer assemblages, Sakai and Nishi (1990) proposed a different age range,

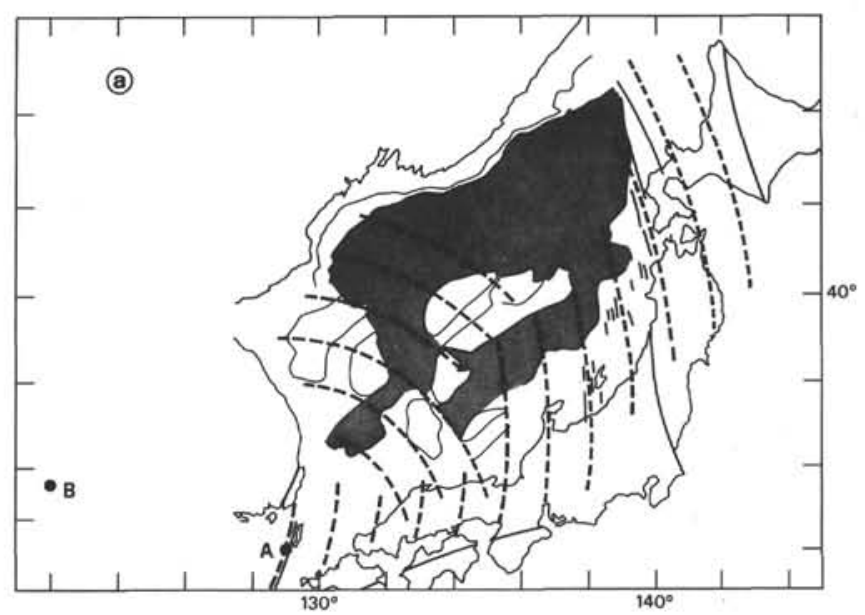

Figure 4. Kinematic model used for reconstruction, shown by the small circles about poles A and B, after Jolivet et al. (1991).

from the late Eocene to the early Oligocene. The best way of assessing the age of the sinistral motion is probably the paleomagnetic results shown by Ishikawa and Torii (1988). These authors infer a counterclockwise rotation of Tsushima Island of some $30^{\circ}$ after the intrusion of a 12 to $15 \mathrm{Ma}$ granite. If counterclockwise rotation is linked with left-lateral motion, it implies a rather recent displacement, most likely after the Japan Sea opening.

Inside this large-scale framework we must take into account the crustal structures described in Tamaki (1988) that imply pre-opening positions for the crustal blocks, such as the Yamato Bank. It is possible to close the Japan Basin by rotating the Yamato Bank back to a position close to the Siberian margin with a good fit of bathymetric curves (Fig. 4). For this purpose one must use a rotation pole located in the Tsushima Strait close to the pole proposed by Otofuji et al. (1985) for a clockwise rotation of Southwest Japan. Although the timing of rotation proposed by Otofuji et al. is in disagreement with the results of ODP drilling (discussed subsequently herein), the pole they proposed is probably suitable. Other data confirm the clockwise rotation of Southwest Japan, such as studies of the deformation associated with the bending of Kyushu (Murata, 1987; Fabbri et al., 1988). Paleomagnetic data in Northeast Japan also suggest counterclockwise rotations during the Japan Sea opening (Otofuji et al., 1985; Tosha and Hamano, 1988). We showed (Jolivet et al., 1991) that such a rotation is necessary to properly close the basin. We thus have a large pull-apart basin opening inside a dextral shear zone, where continental blocks rotate about vertical axes, which is now recognized as classical for strike-slip tectonics.

\section{NEW CONSTRAINTS ON BASIN EVOLUTION BASED ON ODP RESULTS}

\section{Sedimentary Sequence Drilled during Legs 127 and 128}

A complete sequence from lower Miocene to Quaternary was recovered at four sites during Leg 127 (Figs. 1 and 2). Site 794 is located at the center of the Yamato Basin, close to its junction with the Japan Basin. Site 795 was drilled in the northernmost part of the Japan Basin. Site 796 was drilled in the Japan Basin on top of the Okushiri Ridge, which is in active uplift (Tamaki, 1988). Site 797 lies along the northwestern margin of the Yamato Basin, and Site 799, in the Kita-Yamato Trough. Good recovery was obtained at the five sites ( $87 \%$ of mean recovery at Site 794 ). Precise biostratigraphic dates were provided by abundant diatoms in the upper section and some nannofossils farther down (Koizumi, this volume; Rahman, this volume). We thus have good control on the ages of the discrete ash layers referred to later in this paper. The entire sequence is described in 
Tamaki, Pisciotto, Allan, et al. (1990) (Fig. 2). At Sites 794 and 797 it consists of the following:

$1.300 \mathrm{~m}$ of alternating basaltic sills and flows and lower to middle Miocene volcaniclastic sandstones and siltstones, of which the basalts were dated by radiometric methods $\left(\mathrm{K} / \mathrm{Ar}\right.$ and $\left.{ }^{39} \mathrm{Ar} /{ }^{40} \mathrm{Ar}\right)$ at 20 to 16 Ma (Kaneoka, this volume; Pouclet, this volume);

2.100 to $200 \mathrm{~m}$ of calcareous and phosphatic claystones of middle Miocene age and thick "blue tuff" (welded submarine dacitic tuff) beds (up to $20 \mathrm{~m}$ );

3. 80 to $150 \mathrm{~m}$ of upper middle Miocene to lower upper Miocene chert and siliceous clay;

4. $100 \mathrm{~m}$ of upper Miocene diatom clays;

5. 100 to $150 \mathrm{~m}$ of uppermost Miocene to Pliocene diatom oozes; and

6.80 to $100 \mathrm{~m}$ of Quaternary clays.

A dispersed ash component is present in the sediments throughout the sequence, and discrete ash layers as well as consolidated tuff beds $(1 \mathrm{~mm}$ to $10 \mathrm{~cm})$ are in some parts of the section. The last 2 Ma section contains about 100 discrete ash layers, which is one layer for every 20,000 years. This shows that only very large eruptions are recorded as discrete ash layers. Smaller eruptions (the most frequent) are probably evident only in the dispersed ash component.

\section{Timing of Tectonic Events}

The occurrence of basalts and rapid deepening during the early Miocene show that the opening of the Yamato Basin was already active at about $20 \mathrm{Ma}$ (Fig. 5). This contradicts the timing proposed earlier by Otofuji et al. (1985). These authors made a direct relation between the paleomagnetic rotations observed in Southwest Japan and the opening of the Japan Sea, which would have opened, according to their timing, within less than $1 \mathrm{Ma}$ at about $15 \mathrm{Ma}$. The results of ODP drilling are in good agreement with the time span proposed by Tamaki (1988) and also with the rather old magnetic lineations discovered in the northern Japan Basin by Tamaki and Kobayashi (1988). This also fits the age of the "Proto-Japan Sea" determined by Koizumi (1988) with early Miocene brackish water diatoms.

In the center of the Yamato Basin, seamounts are aligned parallel to the trend of the basin. Dredged submarine basaltic volcanics were dated at between 17 and 11 Ma (Kaneoka et al., 1990). Basalts recovered during deep-sea dives along the Okushiri Ridge (Miyashita et al., 1987) were dated to the middle Miocene. Basaltic volcanism was also active along the eastern margin of the Japan Sea between 17 and $13 \mathrm{Ma}$ (Daijima and Nishikurozawa Stages) when the Aosawa basalts were erupted in a deep-sea environment (Tsuchiya, 1989, 1990). All these dates are in agreement with the ODP data. Ages of oceanic basalts and of the oldest sediments deposited on top of them range between 20 and $13 \mathrm{Ma}$.

A comparison can be made with the timing of tectonic events on the margin. Rifting and block tilting along the eastern margin took place during the early and middle Miocene (Suzuki, 1989; Yamaji, 1989, 1990; Amano and Sato, 1989). The stress field associated with the dextral motion is recorded in Cenozoic sediments as young as middle Miocene (Jolivet and Huchon, 1989; Jolivet et al., 1991). Otsuki $(1989,1990)$ reached similar conclusions based on the analysis
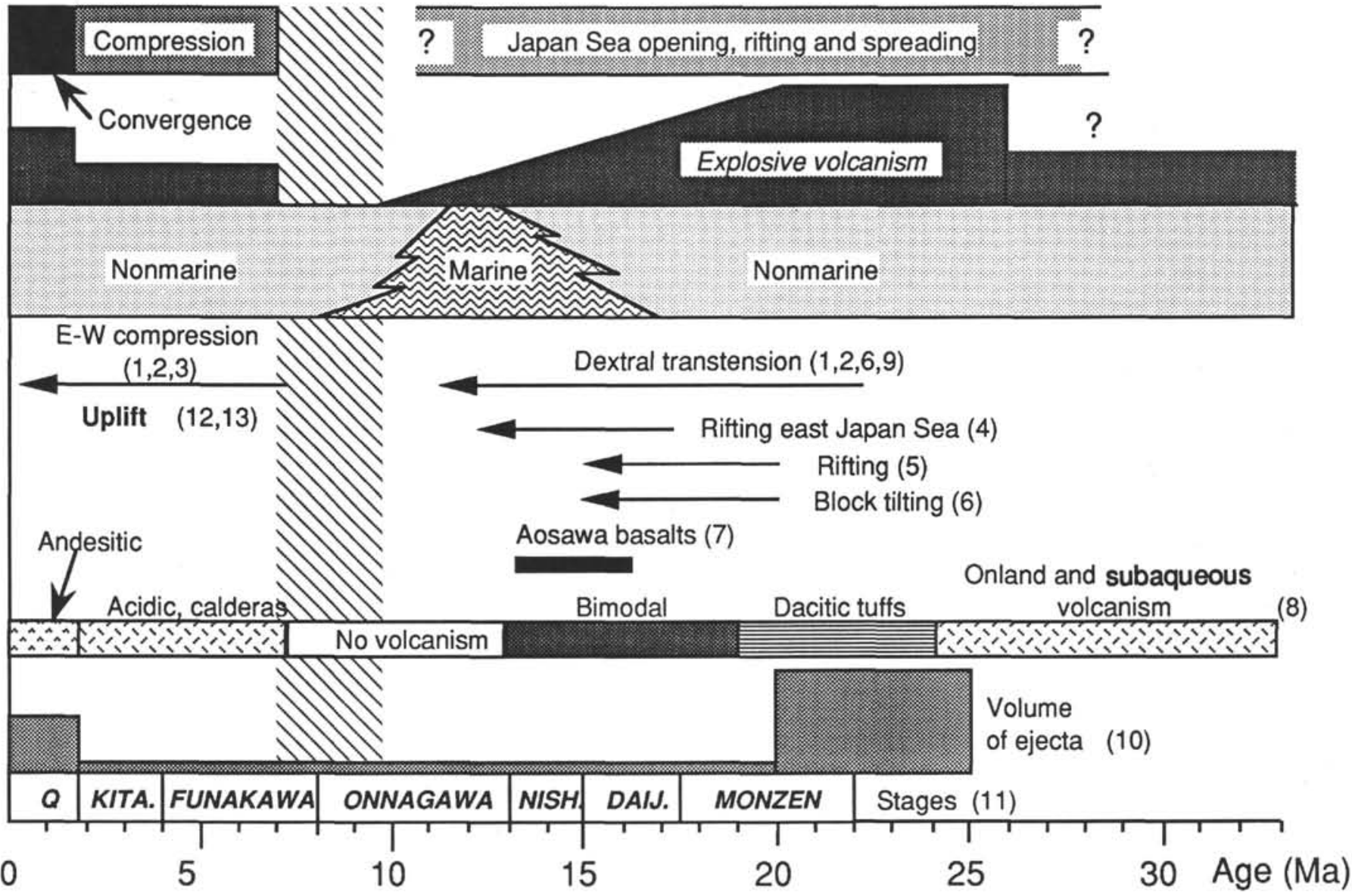

Figure 5. Synthesis of the tectonic and volcanic events in Northeast Honshu, after (1) Jolivet and Huchon (1989), (2) Jolivet et al. (1990), (3) Nakamura and Uyeda (1980), (4) Suzuki (1989), (5) Yamaji (1989), (6) Amano and Sato (1989), (7) Tsuchiya (1989), (8) Usuta (1989), (9) Otsuki (1989), (10) Sugimura et al. (1963), (11) Fujioka (1986), (12) Sugi et al. (1983), and (13) lijima et al. (1988). 
of veins. Suzuki (1989), on the basis of a study of drilled holes in the eastern Japan Sea, concluded that the formation of the "East Japan Rift" system (north-northeast-south-southwest to north-south-trending en-echelon grabens; Fig. 3) was active until 12 Ma. Yamaji (1989, 1990) and Amano and Sato (1989) concluded that rifting and block tilting in the area west of Tohoku occurred before $15 \mathrm{Ma}$.

It appears in conclusion that active spreading in the Yamato and Japan basins, as well as extension along the eastern margin in a strike-slip context, began during the early Miocene and lasted until the end of the middle Miocene, and the total duration of the opening was 5 to $10 \mathrm{Ma}$. The Japan Sea is not a simple oceanic basin with a period of rifting followed by a period of spreading; instead, the deformation of the margins ("rifting," block tilting) continued during the spreading.

East-west compression was superimposed on this dextral transtension; it is recorded in all rocks younger than the middle Miocene (Yamagishi and Watanabe, 1986; Jolivet and Huchon, 1989; Jolivet et al., 1991). It was earlier documented by the trend of dikes by Nakamura and Uyeda (1980) and Takeuchi (1985) from 7 Ma to the present. It was associated with a general uplift of Northeast Japan (Sugi et al., 1983; Iijima et al., 1988). The analysis of subsidence rates in and around the Japan Sea confirms this timing (Ingle, this volume). Ingle showed that uplift started about everywhere $10 \mathrm{Ma}$ and was particularly active along the eastern margin. Only Site 794 shows no uplift in the recent period and shows instead further subsidence. This suggests that while the margins of the basin were being uplifted, the center was subsiding. This can be the result of the onset of compression following a mechanism proposed by Cloething et al. (1985), who described how variations in horizontal stresses in the lithosphere interact with deflections of the lithosphere caused by sedimentary loading. The zone of active thrusting is located at the hinge between these two domains. Drilling at Site 796 resulted in the determination of the age of uplift of the Okushiri Ridge at 1.8 Ma. This age is further interpreted as the age of the beginning of thrusting and convergence along the eastern margin (Tamaki, Pisciotto, Allan, et al., 1990).

In the north, in Sakhalin, dextral shear is probably still active, or, if compression prevails as stated by Rozhdestvenskiy $(1982,1986)$, it corresponds to a very slow convergence. In the Tsushima Strait, Jun (1990) recently proposed new determinations of shallow-focus earthquake source mechanisms by the moment tensor inversion method. Dextral motion with a compressional component is inferred along the Tsushima Fault from his study. This is in agreement with the data shown by Chen and Nabelek (1988) along north-south faults in the Bohai Gulf region. This shows that the dextral shear which was active during the opening is still going on inside the Asian continent far from the subduction zone (see discussion at the end of this paper).

We can summarize the tectonic timing as follows (Fig. 5):

1. From the early to the middle Miocene, the Japan Sea was actively opening as a pull-apart basin between two master dextral faults. Block rotations about vertical axes occurred in the meantime. Deformation was active along the margin and inside the arc during the whole opening process. True oceanic crust was emplaced in the Japan Basin, and thinned continental crust, highly intruded with basaltic dikes and sills, formed in the Yamato Basin.

2. Opening stopped at the end of the middle Miocene. From the late Miocene to $1.8 \mathrm{Ma}$, east-west horizontal compression was active. The whole eastern margin was uplifted.

3. At 1.8 Ma, convergence was initiated along the eastern margin, and normal faults reactivated as thrusts.

The analysis of correlations between these events and the magmatic evolution of the arc, using ash layers recovered in drill holes from the Japan arc, allow us to further the precision of this timing and to suggest links between varying stress conditions and volcanism.

\section{Tectonic Timing and Paleomagnetic Rotations}

The timing discussed above is partly in contradiction with the timing of rotation based on paleomagnetic data. As discussed in several papers (Otofuji and Matsuda, 1983, 1984, 1987; Otofuji et al., 1985, 1991; Tosha and Hamano, 1988; Hayashida, 1986; Hayashida et al., 1991), it is classically admitted that Northeast Japan underwent a counterclockwise rotation and Southwest Japan a clockwise rotation during the Japan Sea opening (Fig. 6). Otofuji et al. (1985, 1991) proposed that both Southwest and Northeast Japan rotated at very high rates about two poles located at either ends of the Japan arc at about $15 \mathrm{Ma}$. Tosha and Hamano (1988) proposed instead that Northeast Japan underwent a slower rotation between 22 and $15 \mathrm{Ma}$. Figure 6 shows the mean values of declination for various sites in Northeast and Southwest Japan after these authors. This figure shows indeed a striking difference between Northeast and Southwest Japan. The apparent rotation of Northeast Japan seems progressive, while that of Southwest Japan seems instantaneous at $15 \mathrm{Ma}$. If one considers, like
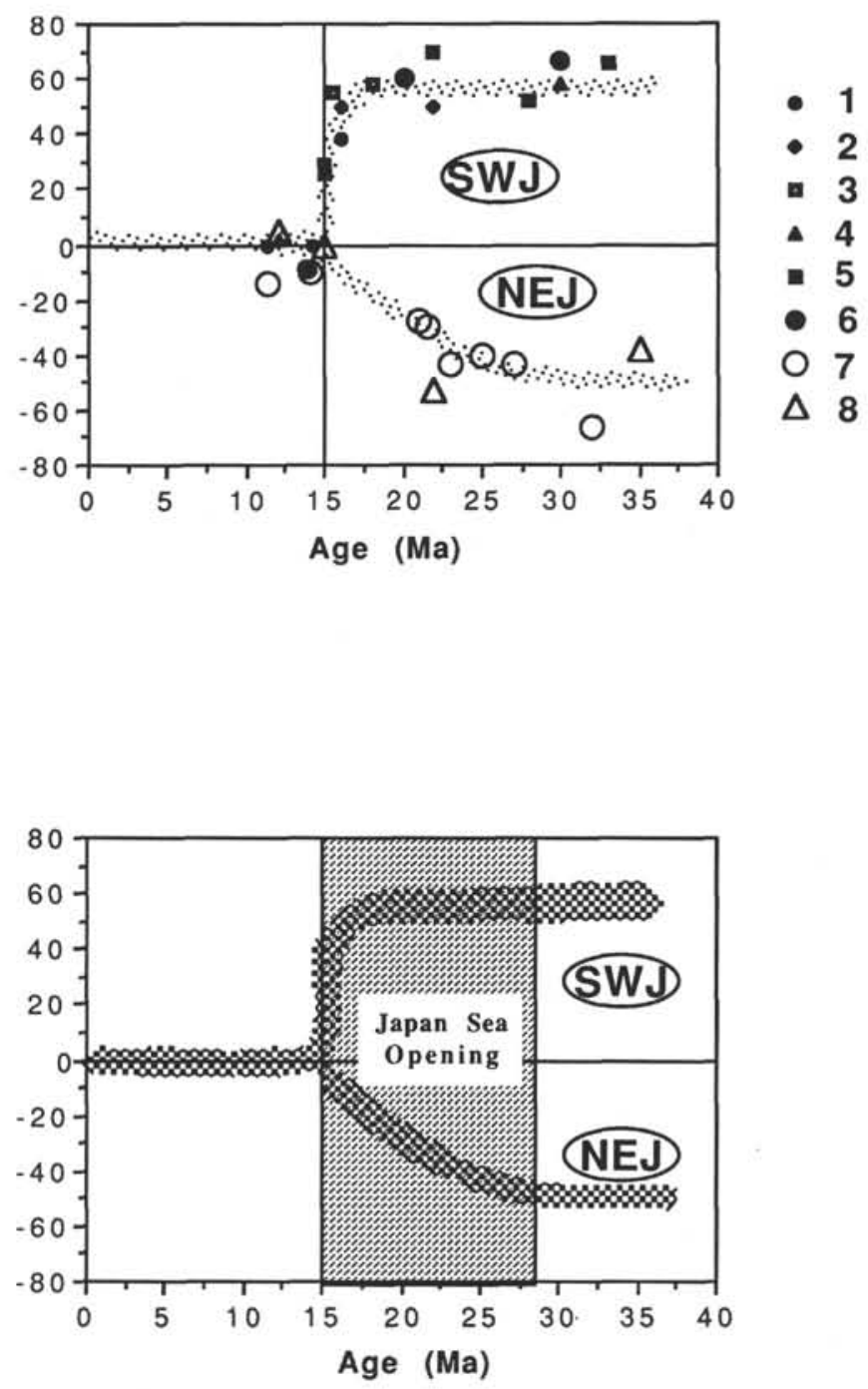

Figure 6. Upper: Mean declination values for Northeast and Southwest Japan vs. age compiled from (1) Otofuji et al. (1991), (2) Hayashida et al. (1991), (3) Hayashida (1986), (4) Otofuji and Matsuda (1983), (5) Otofuji and Matsuda (1984), (6) Otofuji and Matsuda (1987), (7) Otofuji et al. (1985), and (8) Tosha and Hamano (1988). Lower: rotation path for Southwest and Northeast Japan and the period of Japan Sea opening. 
Otofuji et al. (1985), a rigid-body rotation of Southwest Japan, one has to admit a very fast opening of the Japan Sea around $15 \mathrm{Ma}$. The question then is, where is the 15 Ma oceanic crust in the Japan Sea? The results of Legs 127/128 clearly show that the Japan Sea was already widely opened at $20 \mathrm{Ma}$. The possibility arises that this oceanic crust exists in the western part of the Japan Basin, but previous geophysical data (heat flow, magnetic anomalies) show that the Japan Basin is probably as old as 20 to $25 \mathrm{Ma}$ (Tamaki, 1988). Taking the new ODP findings into account, Hayashida et al. (1991) proposed that the opening was first accommodated by a parallel motion of Southwest Japan and then by a fast rotation during the opening of the Yamato Basin. This is unlikely, as we know that the Yamato Basin is older than $15 \mathrm{Ma}$. The rate of rotation given by paleomagnetic data also implies a very fast and unrealistic drifting rate $(60 \mathrm{~cm} / \mathrm{yr}$ !) if Southwest Japan is considered a single block.

There might be at least two reasons for this discrepancy between the timing of paleomagnetic rotation of Southwest Japan and that of the opening:

1. Southwest Japan is not a single block, and rotations are only local: Kanaori (1990) proposed that Southwest Japan can be divided in several blocks which have rotated like dominos in a strike-slip regime. In such a case there is no direct relation between the angle of paleomagnetic rotation and the angle of rigid rotation of Southwest Japan as a whole; it has thus no direct implications on the timing of backarc opening.

2. The fission tracks and K-Ar ages of the rocks used for paleomagnetic measurements are incorrect. We have, however, no a priori reason to disregard these ages.

Yet we have to make a choice for our reconstructions. Given that clockwise rotation of Southwest Japan and counterclockwise rotation of Northeast Japan are needed to take into account the crustal geometry of the Japan Sea, we conclude that:

1. Northeast Japan rotated counterclockwise progressively during the Japan Sea opening about a pole located north of Hokkaido $\left(25^{\circ}\right.$ of rotation in our reconstructions).

2. Southwest Japan as a whole rotated more progressively than is shown by paleomagnetic data during the opening about a pole located in the Tsushima Strait $\left(30^{\circ}\right.$ of total rotation in our reconstructions). The remaining amount of rotation could have been accommodated by local smaller block rotations.

\section{Nature of the Crust and Tectonic Regime}

One of the most important results of recent investigations, including ODP drilling, is that true oceanic crust is restricted to a small part of the backarc domain, in the northeastern part of the Japan Basin. As discussed above, the Yamato and Tsushima basins are likely floored with highly extended arc crust intruded by basaltic dikes. This confers an asymmetric structure to the Japan Sea, with a wide extensional margin to the south and a narrow strike-slip margin to the east (also to the northwest) (Figs. 1 and 7). The narrow margin is in the backarc region of the Pacific subduction, and the wide margin in that of the Philippine Sea plate subduction at present. There might be two reasons for this difference:

1. It can be due to different boundary conditions in the trench region. The old Pacific plate subduction to the east and the young Shikoku Basin lithosphere to the south with different slab geometries led to different stress conditions in the backarc region and consequently induced a different geometry of opening in the backarc region. This hypothesis requires that the Pacific-Philippine-Eurasia triple junction remained stable in its present position through most of the Oligocene and Miocene. This question has been discussed in several papers, and the authors proposed various possible reconstruc-

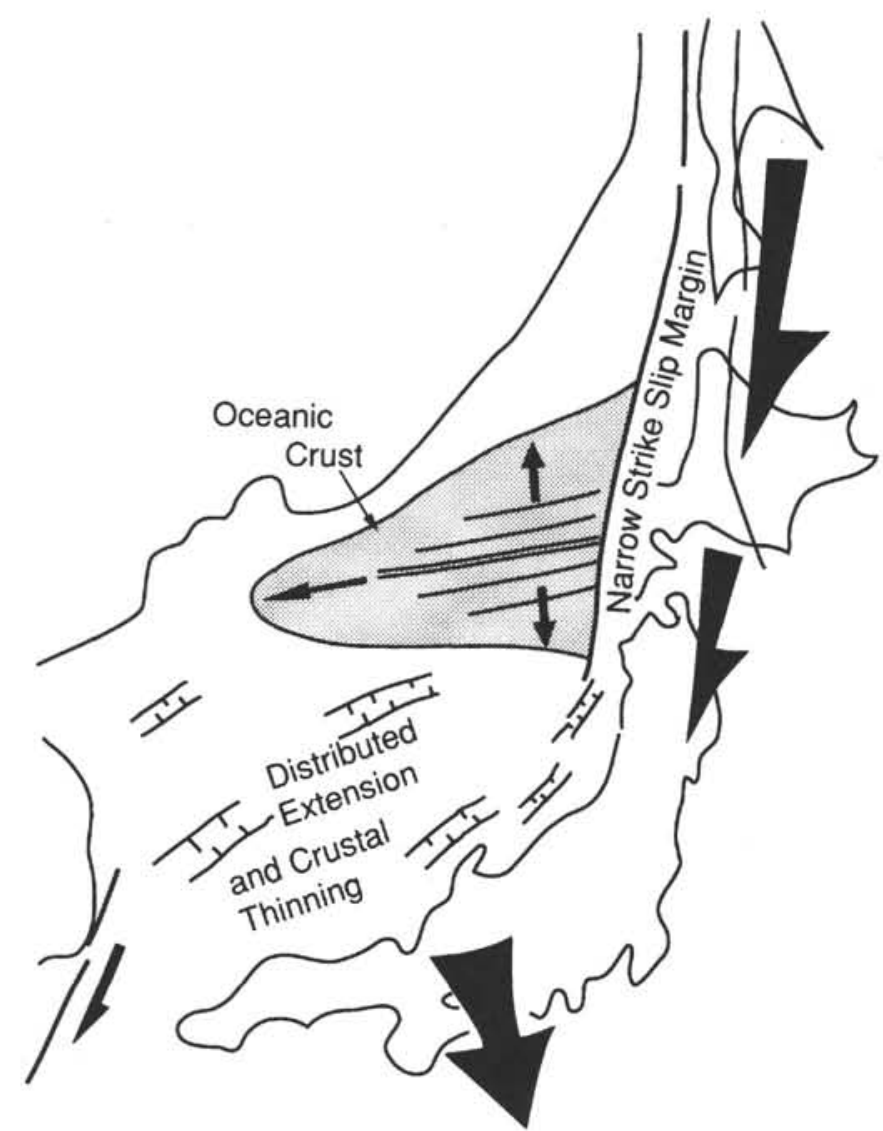

Figure 7. Simplified cartoon depicting the gross mechanism of Japan Sea rifting and spreading, showing the wide extensional margin in the south and the narrow strike-slip margin in the east, as well as the westward propagation of the spreading center in the northern Japan Basin.

tions through the Tertiary. Except for Otsuki (1985), the authors consider that the present triple junction was established through the Miocene and that it migrated northward along the eastern margin of Eurasia to its present position between $18 \mathrm{Ma}$ (Seno, 1985b) to $15 \mathrm{Ma}$ (Jolivet et al., 1989; Taira et al., 1989; Charvet et al., 1990). This solution agrees better with the tectonic evolution of Japan. Collisionrelated structures in the triple junction region are recognized only for the recent period (middle Miocene to present). The subduction of the young lithosphere in the Nankai Trough and the configuration of the triple junction presently induce compressional stresses in the Japan arc instead of the extension required to open a backarc basin. Before settlement of the triple junction near Central Japan, the easygoing Pacific subduction was active under the whole Japan arc and induced extensional stress conditions in the backarc region. The arrival of the Philippine Sea plate, less easily subducted, might have progressively stopped the Japan Sea opening. In this case the difference between the two margins cannot be due to different boundary conditions. We shall then suppose that the extensional conditions created by the Pacific subduction were similar along all of the Japan arc (except in the north at the latitude of Hokkaido and Sakhalin).

2. It can, instead, be due to the geometry of the dextral strike-slip shear zone. Strike-slip deformation is usually more localized along narrow shear zones than is extensional deformation. As shown in Figure 7, one might thus expect more localized deformation along the north-south-trending strike-slip margin than along the east-westtrending extensional margin in the south. The westward propagation of the Japan Basin spreading center described by Kobayashi et al. (1986) fits well in this framework; the oceanic domain in the Japan 
Sea can be envisioned as a propagating crack near the end of the strike-slip shear zone. The next question is the unusual width of the extensional margin (about $400 \mathrm{~km}$ ). Tamaki (1985) noticed that the Japan Sea had a particular rifting behavior with several spreading centers and distributed extension compared to other arcs, such as the Bonin arc, where extension is localized in a single and narrow rift system. The rifting of the Shikoku Basin also occurred along a single narrow rift, as shown by a magnetic anomaly map (Chamot-Rooke et al., 1987). The wider distribution of extension in the Japan Sea might be (1) the result of a different thermal structure with a thicker ductile crust that would distribute the strain in the upper brittle crust, or (2) due to the presence of many preexisting faults that would have weakened the arc crust. This question cannot be solved in this paper.

\section{NEW CONSTRAINTS ON ARC VOLCANIC ACTIVITY BASED ON ODP RESULTS}

The control of magmatic activity by tectonic processes is still poorly understood. Rapid variations in the character of volcanism in a given area are usually linked by the authors to deep-seated changes (in the mantle), which usually provide only few possible tests (Tatsumi et al., 1989). Nakamura (1977) and Nakamura and Uyeda (1980) stated that purely tensional and strike-slip stress regimes favor the ascent of magma in the crust because in both cases the plane that contains $\sigma_{1}-\sigma_{2}\left(\sigma_{1}>\sigma_{2}>\sigma_{3}\right)$ is vertical, and dikes usually intrude along this particular plane. In a typically compressional regime the magma should be confined in sills and not extruded to the surface. This led them to speculate that the active compressional field of Northeast Japan is close to a strike-slip stress field because volcanic activity coexists with thrusting. We show in the following sections that temporal correlations exist between tectonic phases and volcanic phases and propose that the variations observed from the volcanic activity are controlled by deformation of the arc crust rather than by deep-seated processes.

Two peaks of volcanic activity have long been recognized in the Japan region (Sugimura et al., 1963) (Fig. 5): the late Oligocene-middle Miocene "green tuff" volcanism products are widespread in the Japan Sea and Okhotsk Sea sides of the arc. The recent volcanic activity began in the Pliocene. Between the two peaks, a relatively calm period was intercalated, characterized by large eruptions of subaqueous basalts (Aosawa Formation; Tsuchiya, 1989) or by a short interruption of the volcanic activity.

\section{Ash Layers Recovered during Legs 127 and 128}

The discrete ash layers recovered by drilling in marine sediments bring precise time constraints to the explosive volcanic activity along a continuous sequence (Kennett et al., 1977). Cadet and Fujioka (1980) and Fujioka et al. (1986), in studying the ash layers of Deep Sea Drilling Project Legs 57 and 87 (Japan Trench), also recognized two periods of activity with a recess in between (16-8 Ma). Fujioka (1986) concluded that the first peak is broadly contemporaneous with the Japan Sea rifting, and the second peak with the active compression.

The new data obtained at four sites in the Japan Sea during Legs 127 and 128 allow us to further determine precisely the duration of the minimum activity between 10 and $7 \mathrm{Ma}$ (Fig. 8 ). This period corresponds precisely to the change of the stress field from dextral transtensional during the Japan Sea opening to compressional as at present.

During the cruises, each discrete ash layer was described for depth and thickness (the petrography and chemistry of the ashes are described in Pouclet et al., this volume). The conversion from depth to age was made using the dates determined from diatom and nannofossil biostratigraphy (Tamaki, Pisciotto, Allan, et al., 1990) and linear interpolations between these. On the cumulative curves of the number of ash Iayers per core vs. age (Fig. 8) the steep parts denote strong activity, and flat parts a relative calm. We prefer here to count the number of ash layers rather than to measure their thickness. Thickness

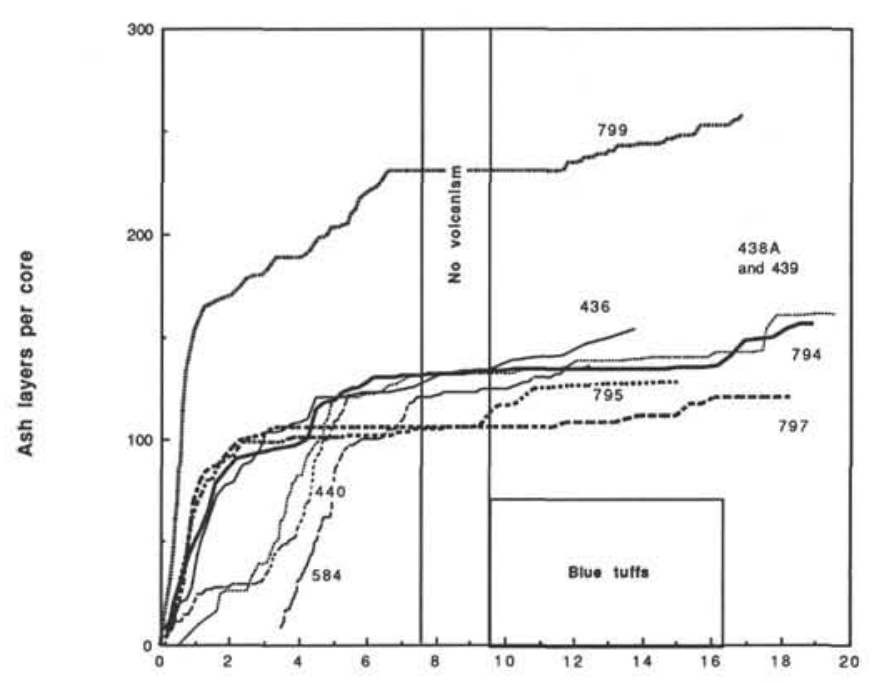

Figure 8. Cumulative curves of the number of ash layers per core vs. age at drill sites around Japan.

variations depend mainly upon the distance between the volcanic center and the region where ashes are deposited, as well as on the intensity of the eruption. It is not impossible that large eruptions occurred during periods of overall low activity at the arc scale. Variations in the number of ash layers per core denote variations in the arc activity as a whole, taking into account all volcanoes of the arc in a single diagram.

Differences visible between the sites can be partly explained by differences in the recovery. We shall immediately eliminate Site 796 from further discussion because it had the lowest recovery and poorer stratigraphic control. Figure 9 shows a plot of the smoothed recovery as a function of depth and age. A low in the recovery is always observed at about $300 \mathrm{~m}$, where the opal-A/opal-CT transition is encountered. At this depth, opal-A is transformed into opal-CT, and cherty layers appear, intercalated with unconsolidated sediments (Tamaki, Pisciotto, Allan, et al., 1990), giving an alternation of different compacted layers that are difficult to recover. The approximately constant depth of this diagenetic transition over the whole basin could have strongly biased the data. Fortunately, the sedimentation rates are very different at the four sites, and the minima in the recovery do not correlate on a plot as a function of age. Figure 9 shows that the minimum of volcanic activity described later (7-10 Ma) is not correlated with the minimum in recovery on the plot as a function of age. It is possible to correct the data for recovery by multiplying the number of ash layers per core by 100 times the reciprocal of the recovery, which changes the relative positions of the curves but not their overall shape. Because we need to compare the data with those of previous DSDP legs in the Japan region, for which we do not have the recovery data, we shall consider in the following section the raw data without correction for recovery and discuss only major variations.

The data show two maxima of explosive volcanic activity, as shown previously by Fujioka (1986) and Cadet and Fujioka (1980). It is useful to compare directly the data of all sites drilled around Japan.

\section{Comparison with Results of Legs 57 and 87}

DSDP Sites 436, 438, 439, 440, and 584 were drilled on the Japan Trench side of the arc at the latitude of Site 794 (Fig. 1). Figure 10 shows a comparison of Sites 794 and 438-439, which had the best recoveries ( $87 \%$ and $63 \%$, respectively). Data for Legs 57 and 87 were taken from Cadet and Fujioka (1980) and Fujioka et al. (1986) and processed in the same way. It appears that the total number of ash layers is roughly similar on either side of the arc. The striking 

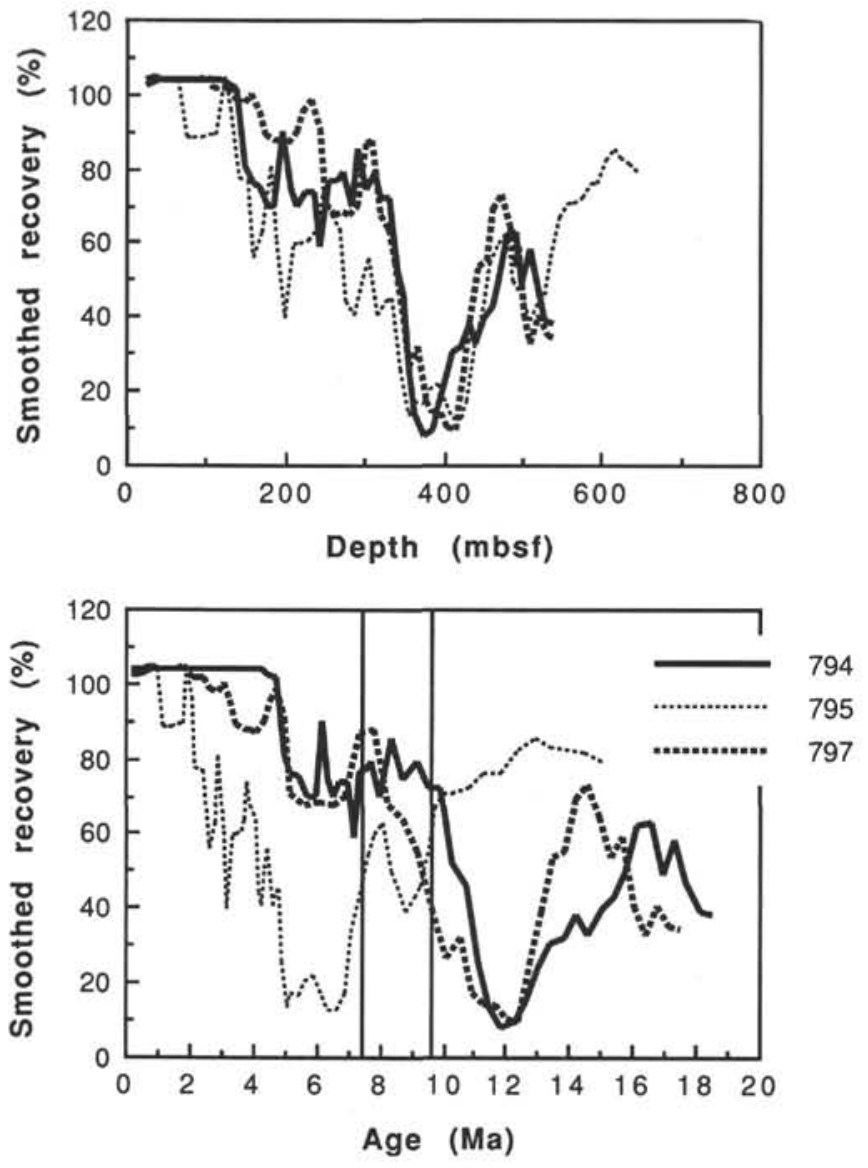

Figure 9. Smoothed recovery as a function of depth and of age. Only the data from above "basement" are shown plotted vs. age.

parallelism of the curves between 4 and $14 \mathrm{Ma}$ further shows that drilling on both sides recovered the same variations in the intensity and that the Japan arc is the most likely candidate for these eruptions.

The disjunction of the curves for the Quaternary and Pliocene, however, should be explained. In Figure 8 the nine sites noted in this paper show two trends for recent periods: Sites 794, 795, 797, and 799 in the Japan Sea and Site 436 on the Pacific plate ("moving site") (Fujioka, 1986) have a "fast" trend, whereas Sites 438, 440, and 584 on the inner wall of the Japan Trench show a "slow" trend. More detailed studies are needed to conclude whether this is real or is an artifact. How can this be explained if it is not due to a problem of biostratigraphic scale? The only important differences between the sites is that the "fast" sites are located in stable environments (deep, flat basins), and the "slow" sites in unstable environments (steep slopes and possible reworking of sediments). The important difference between Site 799 and other ODP sites is that at Site 799 logging data were used to count ash layers in the nonrecovered intervals, which explains why the largest number of ash layers was counted at this site.

Site 436 must be considered separately; as discussed previously by Fujioka (1986) and Fujioka et al. (1986), this site has moved along with the Pacific plate as it approached the Japan arc during the Neogene at an average rate of $10 \mathrm{~cm} / \mathrm{yr}$. The ash layers recovered at this site are thus significant for the evolution of the Japan arc only for recent time. This may explain the particular behavior of Site 436 before $6 \mathrm{Ma}$; when other sites have rather flat cumulative curves, Site 436 has a regular positive slope that indicates a constant supply of volcanic products that did not reach the fixed sites and thus did not originate from the Japan arc.

Except for these restrictions, and if we consider only the first-order variations, Figure 8 shows two periods of explosive volcanic activity:

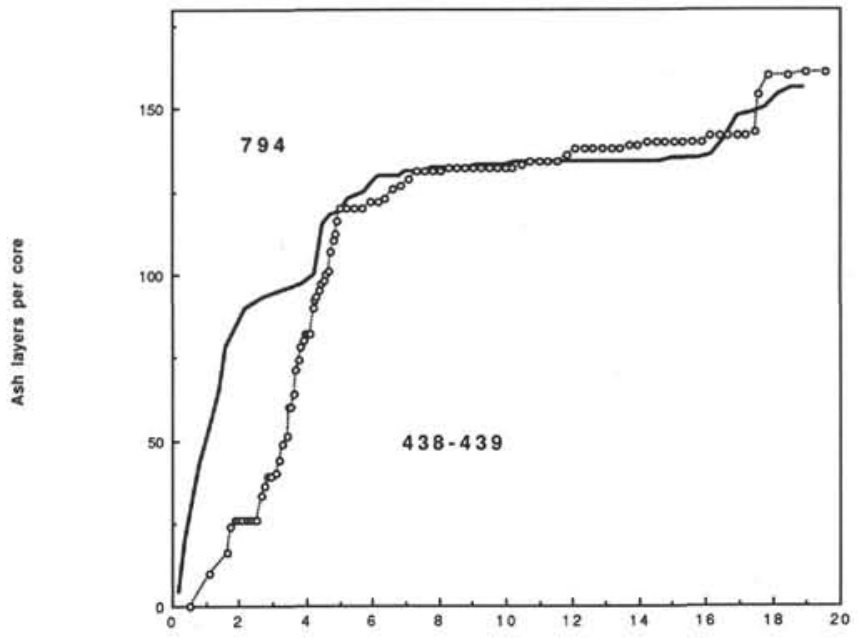

Figure 10. Cumulative curves of the number of ash layers per core vs. age for Sites 794 and 438.

0-7 and 10-20 Ma. Between these two peaks all curves are flat. We record here a minimum of aerial explosive volcanism between 10 and $7 \mathrm{Ma}$. Also, the period 20-10 Ma is far less active than the recent one.

\section{Artifact or True Minimum of Volcanic Activity}

A minimum in the aerial explosive volcanic activity may have two different causes: it is either a period of low volcanic activity or a period of subaqueous activity if a large transgression occurs. A marine incursion actually occurred in the Northeast Japan arc between 16 and $8 \mathrm{Ma}$ (Fig. 5), but its maximum was about 12-13 Ma and was followed by a fast regression from 12 to $8 \mathrm{Ma}$ (Usuta, 1989; Yahata, 1989; Suzuki, 1989; Iijima et al., 1988). The minimum recorded in the ash layers is thus offset by 2 or $3 \mathrm{Ma}$ with respect to the marine transgression. We can further argue that although the present-day Bonin arc is largely under water, aerial volcanic activity has occurred and been recorded in the sediments as ash layers (Taylor, Fujioka, et al., 1990).

Furthermore, Usuta (1989) also described, on the basis of on-land studies along a transect of the Japan arc at the latitude of Akita Prefecture, a period of starvation of the volcanism between 13 and $8 \mathrm{Ma}$.

We consider in the following paragraphs that the volcanic activity of the whole Northeast Japan arc has been starved during a short interval between 10 and $7 \mathrm{Ma}$. The Neogene of Northeast Honshu is classically divided into seven stages (Fig. 5): Monzen Stage (22-17.5 Ma) with andesites and high-alumina basalts, Daijima Stage (17.5-15 $\mathrm{Ma}$ ) with dacites and rhyolites of calcalkaline affinity, Nishikurozawa Stage (15-13 Ma) with calcalkaline aerial volcanism to the east and submarine basalts to the west, Onnagawa Stage (13-8 Ma) of dacitic and basaltic volcanism, Funakawa (8-4 Ma) and Kitaura Stages (4-1.8 Ma) with dacites and granodiorites, and the Quaternary with andesites (Fujioka, 1986). More recently, various authors (Usuta, 1989; Yahata, 1989; Ito et al., 1989) described the evolution of Northeast Japan as follows: the volcanism started as early as $33 \mathrm{Ma}$ with on-land and subaqueous eruptions; between 22 and $19 \mathrm{Ma}$, dacitic tuffs were widespread, followed by bimodal volcanism active until $13 \mathrm{Ma}$; and, after an interruption between 13 and $8 \mathrm{Ma}$ as previously noted, the volcanism resumed with explosive acidic volcanism and the formation of large calderas until $2 \mathrm{Ma}$, when the present-day andesitic activity took over.

The whole history of the arc is aerial except for the Daijima, Nishikurozawa, and Onnagawa Stages, when marine transgression occurred with a maximum at $12 \mathrm{Ma}$. The undersea basaltic eruptions 
of the Aosawa Formation occurred along the western coast of Honshu around $15 \mathrm{Ma}$ (Tsuchiya, 1989). Estimates of the volume of ejecta show two maxima, with the largest between 20 and $25 \mathrm{Ma}$ and a less important one from $2 \mathrm{Ma}$ to the present (Sugimura et al., 1963).

Correlation can then be made with the tectonic activity of the arc and the timing of opening and closing of the backarc. Volcanism was highly active during the rifting and spreading of the Japan Sea, starting with aerial volcanism and ending with submarine eruption of the Aosawa Formation at about $15 \mathrm{Ma}$. Volcanism was very active also during the recent period when east-west compression prevailed, starting with explosive acidic volcanism and the formation of calderas from 7 to $2 \mathrm{Ma}$ and andesitic volcanism in the Quaternary. We thus have two correlations: (1) the minimum of volcanic activity recorded in the drill holes is contemporaneous with a change of the stress pattern in the arc from tensional to compressional, and (2) the formation of large calderas corresponds to the period when the arc was under compression before the inception of the underthrusting zone along the eastern margin, which must have partly released stress across the arc.

\section{RECONSTRUCTIONS FROM 25 MA TO THE PRESENT}

Taking into account the tectonic and volcanic timing discussed previously, we describe reconstructions (Figs. 11 through 16) and discuss their tectonic implications. We present our reconstructions of the six stages from $25 \mathrm{Ma}$ to the present. From the present stage (Fig. 11) the six Leg 127 and 128 sites are represented by large black dots, for which we move back in time through the figures until the period of the oldest rock encountered in each hole. For each given stage only the structures that were active at this given period are shown, and only the Japan Sea region is shown on these reconstructions. Reconstruction parameters are listed in Table 1, and the evolution is shown in cross section in Figure 17. As shown in Figure 17, the contrasting evolutions shaped the northern and southern parts of the Japan Sea. The opening in the southern section was achieved mainly by crustal extension rather than by oceanic spreading. The resulting topographic expression is abundant continental fragments in the southern Japan Sea and widespread oceanic crust in the north.

\section{Present (Fig. 11)}

Active convergence occurs along the eastern margin of the Japan Sea. Normal faults are reactivated as thrust faults, and active uplift occurs in the Hidaka Mountains. This convergent zone extends southward in the Fossa Magna region along the Itoigawa-Shizuka Tectonic Line. Turbidites are being deposited across the area. Andesitic volcanism is active in the Northeast Japan and Kuril arcs above the Pacific subduction zone. The volcanic front has been fixed since 12 Ma. Pacific subduction proceeds at about $10 \mathrm{~cm} / \mathrm{yr}$ northwestward. Active erosion and gravity sliding affect the inner wall of the Japan and Kuril trenches (Cadet et al., 1987). Slightly oblique convergence under the Kuril arc (eastern Hokkaido) produces a right-lateral displacement along the Kamishiyubetsu Tectonic Line in the volcanic front region (Kimura, 1986). The Philippine Sea plate subducts below Southwest Japan at about $4 \mathrm{~cm} / \mathrm{yr}$ toward the northeast (Seno, 1977; Huchon, 1985; Ranken et al., 1984). Collision with the Bonin arc is active in Central Japan along the Kannawa Thrust. Active thrusting affects the Philippine Sea oceanic crust and part of the Bonin arc crust along the Zenisu Ridge and possibly south of the Zenisu Ridge (Lallemant et al., 1989; Le Pichon et al., 1987). Progressive accretion of the Bonin arc is in progress (Taira et al., 1989; Soh et al., 1991). Oblique subduction in the Nankai Trench induces a dextral motion along the Median Tectonic Line. Dextral motion is active in the Tsushima Strait.

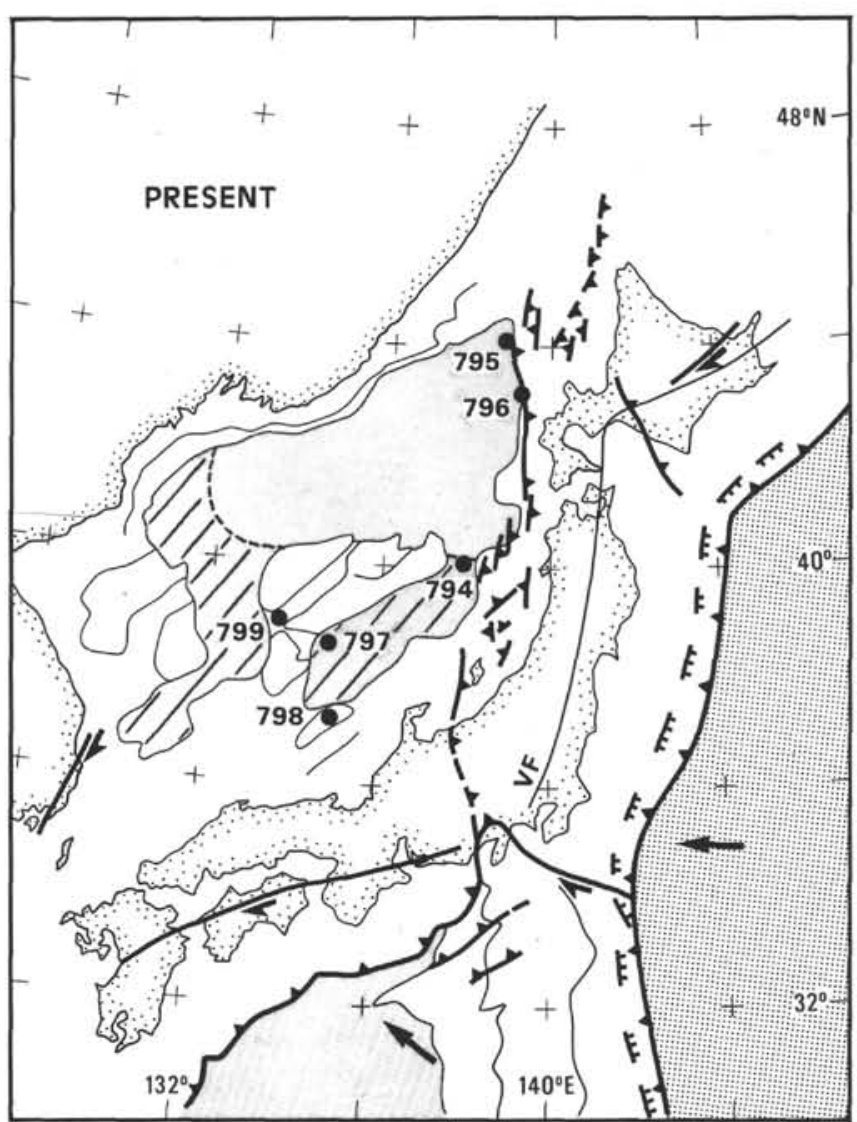

Figure 11. Present-day geodynamic situation in the Japan Sea region. VF = volcanic front.

\section{Late Pliocene-Early Quaternary (1.8 Ma) (Fig. 12)}

During this stage a small amount of east-west convergence was removed along the eastern margin of the Japan Sea. Because a transition from slow dextral shear to east-west convergence is observed between Hokkaido and Sakhalin, the Northeast Japan-Asia rotation pole was placed there $\left(47^{\circ} \mathrm{N}, 140^{\circ} \mathrm{E}\right)$. A slow motion of $0.44^{\circ} / \mathrm{m}$.y. $\left(0.6 \mathrm{~cm} / \mathrm{yr}\right.$ at $\left.40^{\circ} \mathrm{N}, 140^{\circ} \mathrm{E}\right)$ was applied. The Philippine Sea plate was rotated back about the pole proposed by Huchon (1985). We assume that thrusting was already active along the Zenisu Ridge but not south of the Zenisu Ridge. The general picture is similar to that of the present except for one major point: this is the time of initiation of convergence along the eastern margin, which partly released the compressional stress across the arc, and of transition from acidic to andesitic volcanism.

\section{Middle Miocene (12 Ma) (Fig. 13)}

The geometry in the Japan Sea is similar to that of the PlioceneQuaternary, as neither active convergence nor active opening has occurred between these two stages. The probable east-west intra-arc shortening initiated in the late Miocene is negligible, given the scale of the reconstructions. Between these two stages, an important period was at about 8-10 Ma, when the stress field in the Northeast Japan arc changed from transtensional to compressional. This period has seen a starvation of volcanic activity (see evolution in cross section in Fig. 17). The onset of compression produced the uplift of the arc and the Yamato Bank and subsidence of the basinal parts (Site 794) close to the margin. 


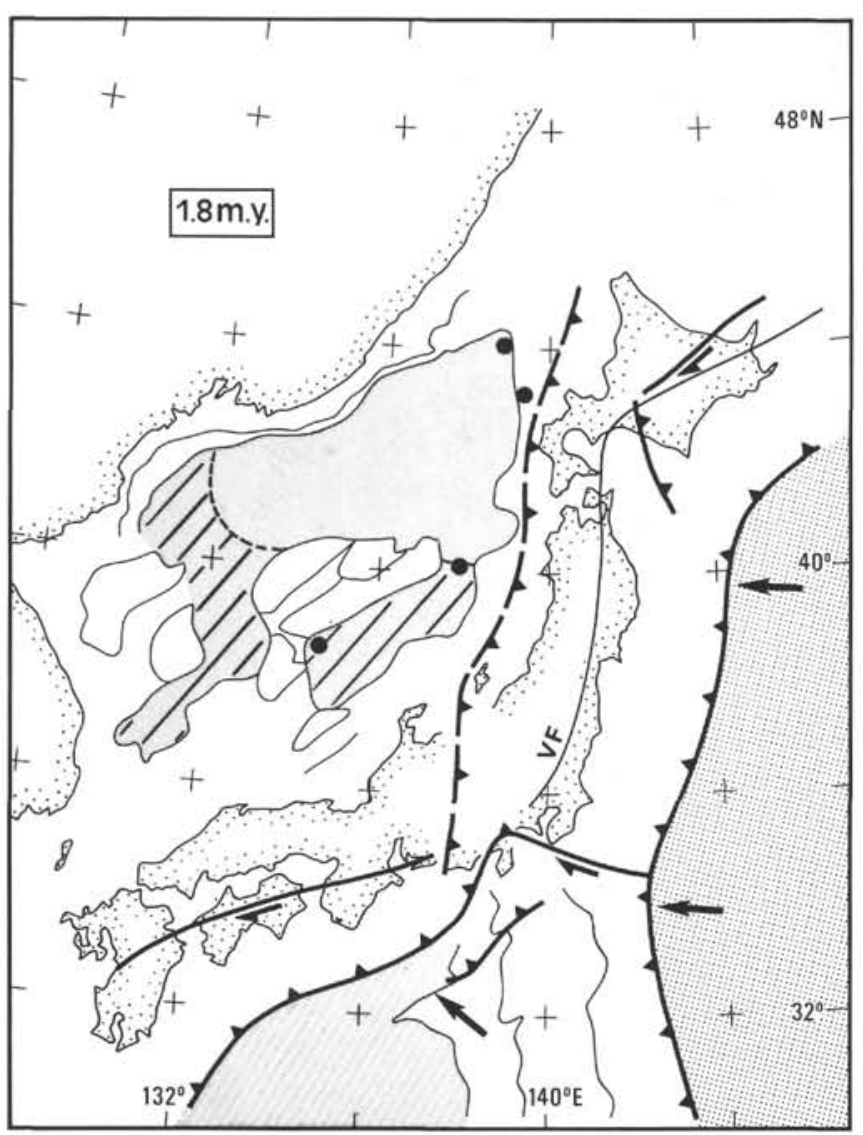

Figure 12. Reconstruction at 1.8 Ma, Japan Sea region.

At $12 \mathrm{Ma}$, extension was still active only along the northeastern margin but in its last stage. Basaltic volcanism produced a chain of seamounts in the Yamato Basin. This evolution is similar to that of the Shikoku Basin, where the Kinan Seamount Chain was formed after cessation of spreading in the late stages of opening at the same period. The Philippine Sea plate has been rotated back to the south using parameters given in Jolivet et al. (1989). The geometry of the Bonin arc at this period is unknown. We can say, however, that collision was already active and that ophiolite was emplaced along the collision zone (Mineoka ophiolite, Taira et al., 1989; Ogawa, 1983), although the exact timing is not precise. The volcanic front in Northeast Japan had just reached its present position. The last increments of dextral motion along the eastern margin were completed. En-echelon folds and thrusts formed in Hokkaido, and en-echelon grabens formed along the eastern margin of the Japan Sea. Erosion was active along the Pacific subduction zone and slowly reduced the width of the Northeast Japan arc.

\section{Late Early Miocene (15 Ma) (Fig. 14)}

Blocks were rotated backward in order to subtract the opening that occurred between 15 and $12 \mathrm{Ma}$. Northeast Japan was rotated about a pole located at $38.5^{\circ} \mathrm{N}, 122^{\circ} \mathrm{E}$, which fits the transfer faults along the eastern margin (Jolivet et al., 1991). This north-south translation is unlikely to be seen in the paleomagnetic data (the counterclockwise rotation of Northeast Japan is accommodated in the next step at 20 Ma). Eastern Hokkaido was given the same rotation plus a component of north-south displacement in order to accommodate the compressional component along the northern part of the strike-slip shear zone. Southwest Japan was rotated using the pole in the Tsushima Strait

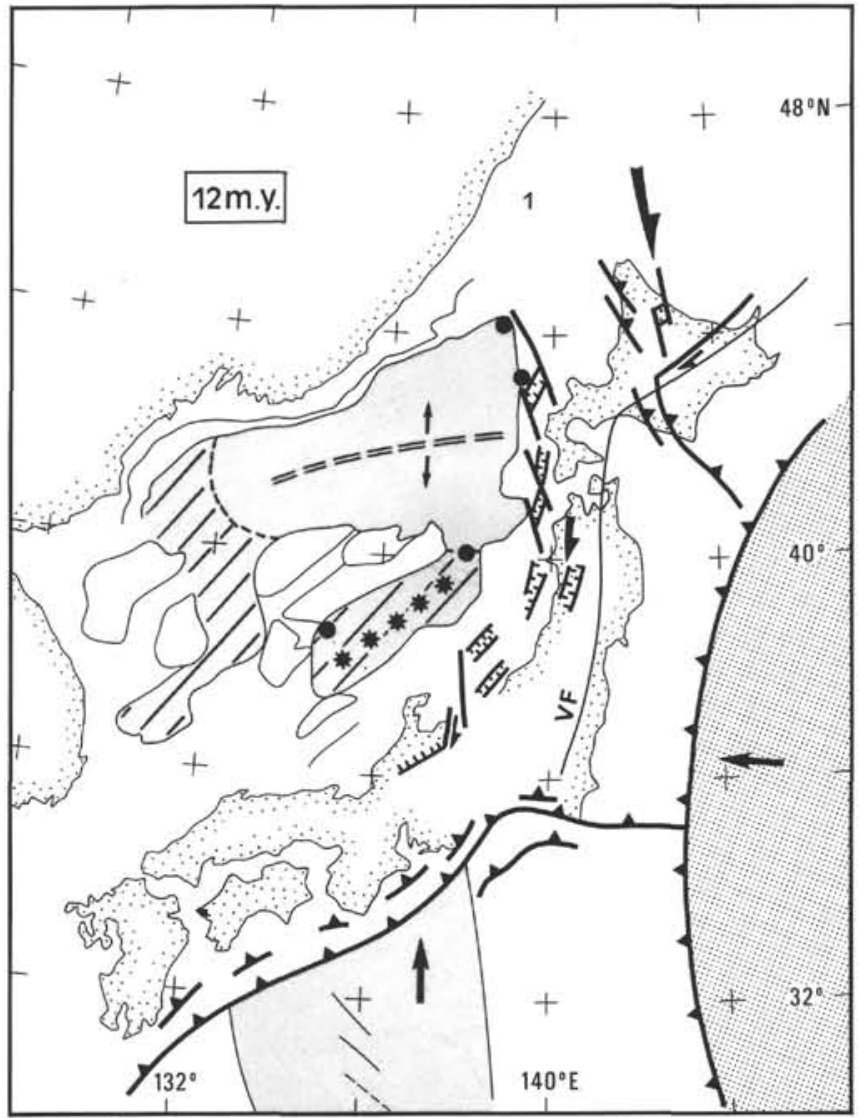

Figure 13. Reconstruction at $12 \mathrm{Ma}$, Japan Sea region.

$\left(34^{\circ} \mathrm{N}, 129^{\circ} \mathrm{E}\right)$ to accommodate the clockwise rotation. Dextral motion was active along the Tsushima Strait, and the Pohang and Ulleung basins were formed as pull-apart basins. In general, the direction of opening was north-south along east-west-trending ridges. En-echelon grabens were forming along the eastern margin of the Japan Sea, and all of the Northeast Japan arc was under oblique extension. The volcanic front in Northeast Japan was located eastward of its present position and was moving westward in response to the shortening of the arc due to tectonic erosion along the Japan Trench. Spreading was active in the Shikoku Basin, which was subducted northward in the proto-Nankai Trench. At about $15 \mathrm{Ma}$ the Philippine-Eurasia-Pacific triple junction was settled close to its present position.

\section{Early Miocene (20 Ma) (Fig. 15)}

The two basins (Japan and Yamato) appear narrower in the early Miocene than in the previous stage. This is the period of maximum spreading and extension in the arc. Only Sites 794, 797, and 799 are shown. The arc is much wider and the volcanic front far eastward of its present position due to tectonic erosion between 15 and $20 \mathrm{Ma}$. Dextral motion was active along the eastern and western master faults, with a transition from transpression to transtension from north to south. The Philippine Sea plate is not shown because the triple junction was located far southward (see Jolivet et al., 1989). The Pacific plate subducted under the entire Japan arc and acted as a low-stress condition on the eastern side of the dextral shear zone, thus creating the extensional condition necessary for backarc opening (see following discussion). One can speculate that the arrival of the Philippine Sea plate from 15 Ma might have changed this boundary condition toward a more compressional one and progressively stopped the opening. 


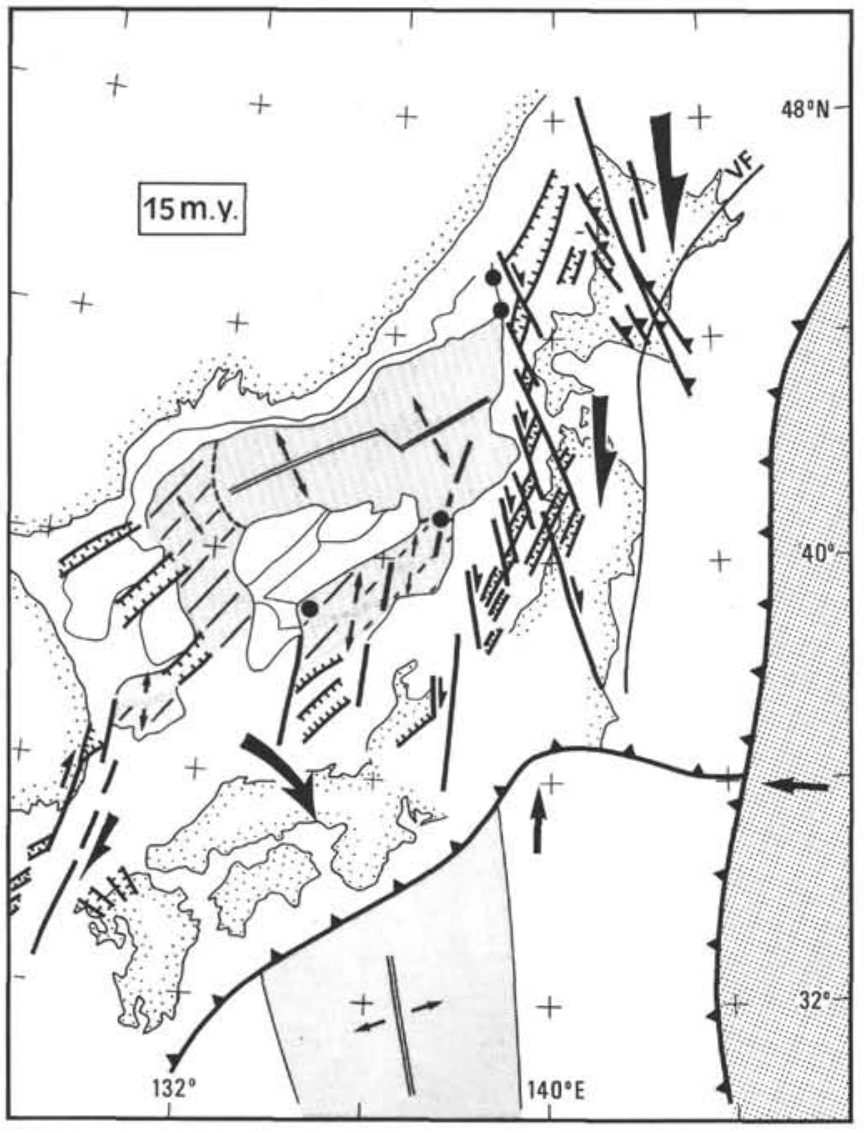

Figure 14. Reconstruction at $15 \mathrm{Ma}$, Japan Sea region.

\section{Early Early Miocene (25 Ma) (Fig. 16)}

This is approximately as far as we can go in the past at this scale, given the present set of data. The Japan Sea was only an intracontinental sea with brackish-water conditions. No oceanic spreading had really begun at this stage. Japan was in its pre-opening position. Southwest Japan was rotated back in order to accommodate both clockwise rotation and dextral motion along the Tsushima Strait, and Northeast Japan was rotated back in order to accommodate dextral motion along the eastern margin of the Japan Sea and counterclockwise rotation. This gives a pre-opening reconstruction in which the bent shape of the arc is not seen anymore. En-echelon grabens were forming inside the dextral shear zone, which forms a single feature from north to south. The first intrusions of oceanic crust were emplaced near Site 797 between 25 and 20 Ma. Reducing the width of the arc to subtract intra-arc extension brings the volcanic front westward with respect to its position at $20 \mathrm{Ma}$.

\section{DISCUSSION}

\section{Volcanism and Tectonics}

Detailed analysis of individual volcanoes or dike systems provides general insights into the way magma intrudes the upper brittle crust. A study of the Inyo dike (Long Valley caldera, California; Reches and Fink, 1988) suggests that intrusion is controlled by the active tectonic stress field and ignores even large fractures not related to the present tectonic activity. Evarts et al. (1987) and Weaver et al. (1987) showed that the intrusion of magma at Mount St. Helens is tectonically controlled by local crustal spreading in right-lateral offset along the dextral St. Helens seismic zone. The ascent of magma is permitted by a favorable fault geometry and stress field, which allow local exten-

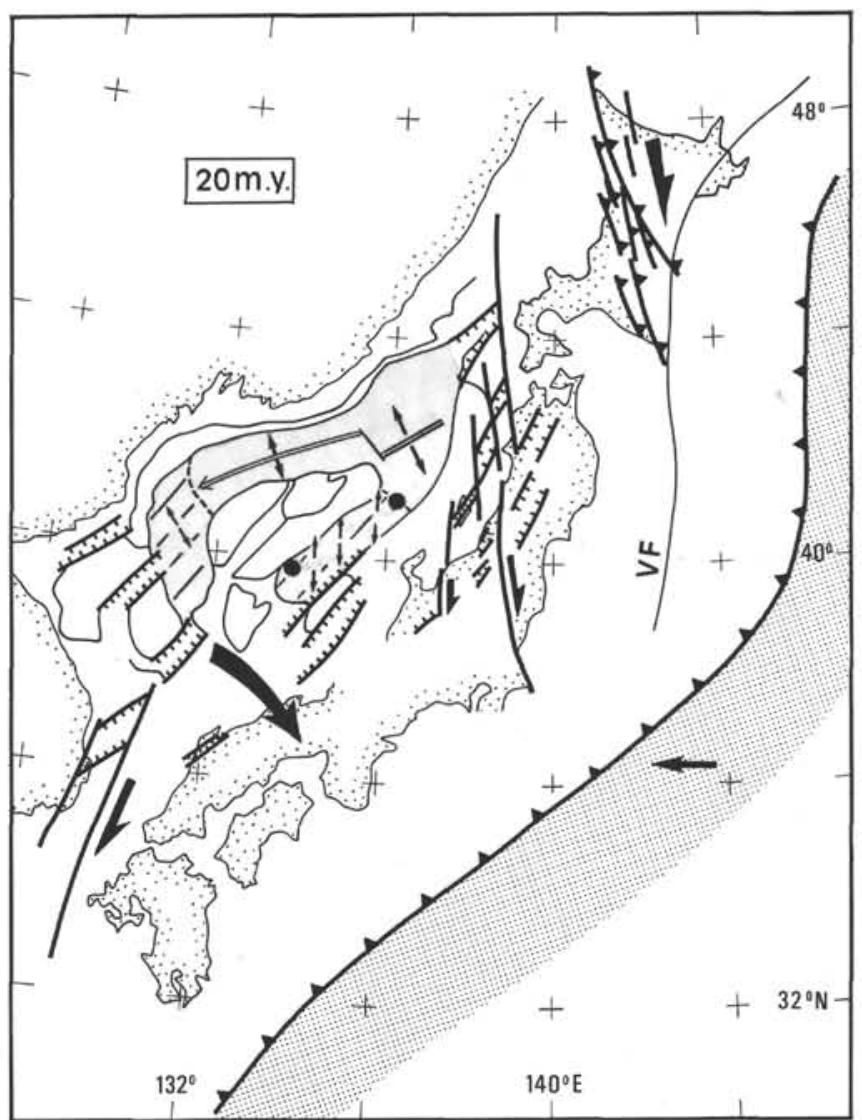

Figure 15. Reconstruction at $20 \mathrm{Ma}$, Japan Sea region.

sion in a strike-slip environment. These studies suggest that crustal deformation is necessary to allow, or at least to favor, magma intrusion in the upper crust. In the case of the Japan arc this suggests that during the transition from extension to compression in the late Miocene the arc was in a short quiet period with low strain that did not allow the ascent of magma through the upper crust. One possibility is that, during the transition from transtension to compression, the arc encompassed a period of isotropic stress conditions during which the formation of cracks was not allowed.

Several papers describe the state of stress of an arc. Nakamura and Uyeda (1980) explained the lateral stress field changes from compression in the trench to extension in the backarc region by keeping the vertical stress constant and assuming that the horizontal stress transmitted by the subducting plate through the subduction plane decreases toward the backarc. Froidevaux and Isacks (1984) considered instead the effect of topography, assuming a constant horizontal stress that gets smaller than the vertical stress when high topographic relief occurs. This second model explains well the extension in the high plateau of the Andes and the rifting at the center of the Bonin arc, where the topographic expression is at a maximum. Froidevaux et al. (1988) further estimated the value of the stress transmitted from the slab in arcs where extension occurs (Mariana type) and those where compression prevails (Chilean type). Recently, Bott et al. (1989) through finite-element modeling investigated the influence of mechanical coupling along the subduction contact and concluded that a steeply dipping slab with a low coupling is likely to induce trench suction as well as extension in the arc and backarc region, which confirms the distinction between Mariana and Chilean type subduction zones by Uyeda and Kanamori (1979).

Following Froidevaux and Isacks (1984), one can assume that at the center of the Northeast Japan arc the topography is high enough 


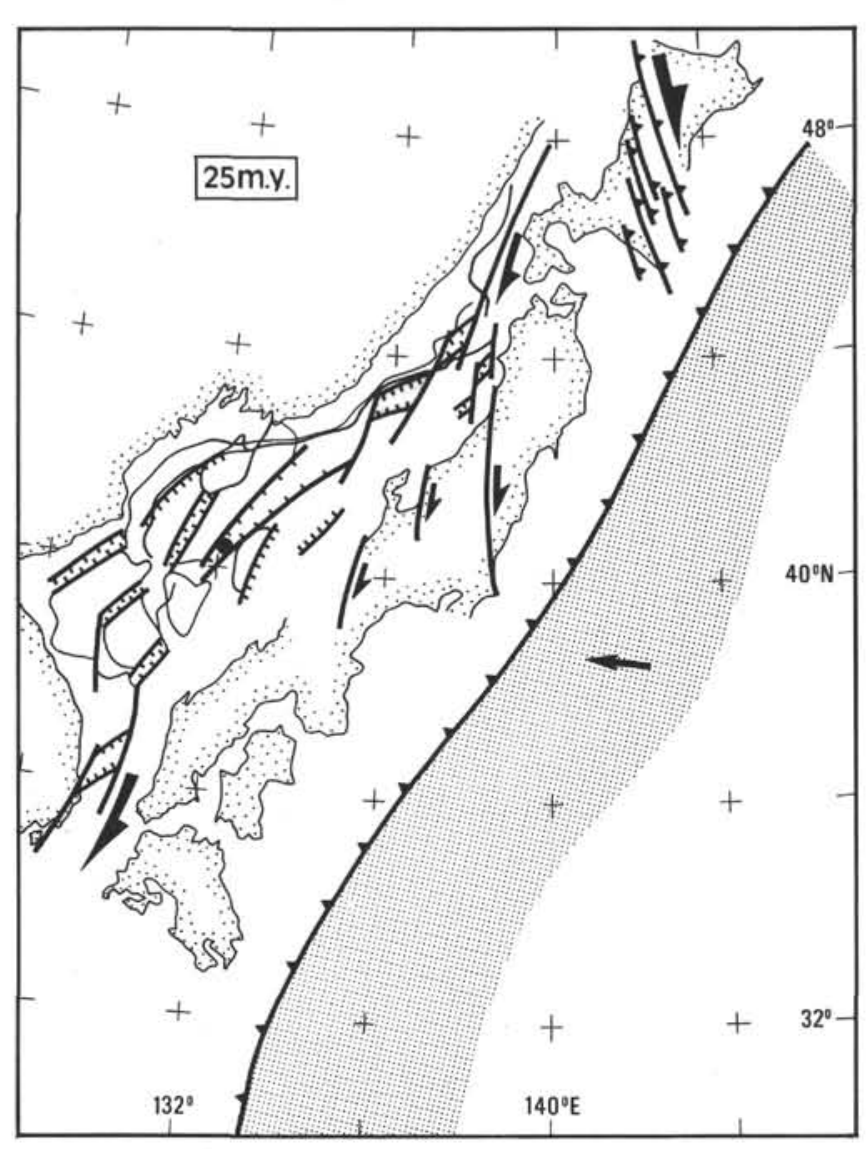

Figure 16. Reconstruction at $25 \mathrm{Ma}$, Japan Sea region.

so that $\sigma_{\mathrm{v}}=\sigma_{2}, \sigma_{\mathrm{H} \max }=\sigma_{1}$, and $\sigma_{\min }=\sigma_{3}$, thus leading to strike-slip deformation for the recent period. One may further assume that before the inception of underthrusting on the eastern margin of the Japan Sea the horizontal compressional stress was higher than at present and that a more compressive stress field consequently prevailed, thus decreasing the possibility for the magma to reach the surface. The magma had to stay longer in deep magma chambers, where it could differentiate until the formation of a caldera.

These hypotheses might better explain the abrupt variations observed in Northeast Japan in the stress field and volcanic activity than changes in the upper mantle below the arc, given that (1) there was no obvious change of either the direction or the rate of subduction of the Pacific plate during the Neogene, which could explain the drastic changes observed at about $8 \mathrm{Ma}$ and at $1.8 \mathrm{Ma}$; and (2) there are no obvious differences in the subducting plate north and south of the Central Japan triple junction, where compression and extension, respectively, occur at present in the Japan and Bonin arcs.

This suggests that the magmatic supply from deep-seated environments has been kept constant through time and that the variations observed at the surface are most likely due to more superficial changes, such as the tectonic status of the crust, as discussed previously. We voluntarily ignore possible deep-seated changes to explore the possibility that deformation of the arc crust triggered the variations in the magmatic activity.

It is also necessary to look for an explanation for the migration of the volcanic front from $30 \mathrm{Ma}$ to the present. Ohguchi et al. (1989) recently described the different positions of the volcanic front (Fig. 1) during the Neogene. The front was located in the backarc side of Northeast Japan in the late Oligocene, after which it migrated eastward to a new position close to DSDP Site 439 near the present-day Japan Trench at $20 \mathrm{Ma}$. In Figure 1 only the positions at 30 and 20
Ma are shown, but the data described in Ohguchi et al. (1989) show intermediate positions and a progressive eastward migration. The front then moved westward until $10 \mathrm{Ma}$, when it reached its present position. Tatsumi et al. (1989) explained these variations by changes in the dip angle of the slab with time. One basic assumption of their paper is that an asthenospheric injection at 30-23 Ma caused a steepening of the slab and eastward migration of the volcanic front (the successive positions of the volcanic front from 30 to $0 \mathrm{Ma}$ are shown in Fig. 1). The observations this assumption is based on are (1) the larger width of the Oligocene volcanic arc compared to more recent periods, and (2) the fact that no spreading or extension process was active at this period in the backarc, which could explain point (1). But we know that the Yamato Basin had already opened widely and that rifting was active in the early Miocene. It is thus possible that the greater width of the Oligocene volcanic arc is a consequence of the Oligocene-Miocene extension and spreading rather than a sudden steepening of the slab.

If one assumes (Fig. 18) that (1) the geometry of the slab has been constant with time (constant dip angle), and (2) extension in the arc region during the rifting between 30 and 20 Ma resulted in homogeneous stretching of the upper plate lithosphere, the distance D between the trench and the volcanic front, which is dependent only on the slab dip angle, must be kept constant with time, and the distance $\mathrm{d}$ between the volcanic fronts at 30 and $20 \mathrm{Ma}$ is a function of $\mathrm{D}$ and the extension coefficient $\beta$. These simple assumptions lead to $\beta=1.8$ in the case of the Japan arc between 30 and $20 \mathrm{Ma}$ for the region located between the 30-Ma volcanic front and the present Japan Trench, which is not unreasonable. The westward motion of the volcanic front afterward could have been due to tectonic erosion (von Huene and Cullotta, 1989; von Huene and Lallemand, 1990).

We reconstruct the evolution of volcanic activity in our reconstructions as follows (Figs. 17 and 18): The first period (30 Ma) corresponds to the inception of rifting in the late Oligocene with the production of a huge amount of volcanic products, the "green tuff" period. During the second period $(20 \mathrm{Ma})$ the opening progressed, a part of the arc subsided, and basic volcanic activity progressively shifted on the backarc side with the production of large basaltic eruptions. Because the arc was also under extension, arc volcanism was active. The extension and spreading in the upper plate and retreat of the slab oceanward resulted in a migration of the arc sliver eastward with respect to fixed Eurasia. Intra-arc extension resulted in the eastward migration of the 30-Ma volcanic front and enlargement of the 30-Ma volcanic zone. After a starvation of volcanism after the end of opening and before the beginning of compression, the fourth stage involved active compression across the whole arc, whereas the fifth stage experienced convergence along the eastern margin. During the recent stages, magma intruded along the highest topographic line, where strike-slip conditions are met as discussed earlier. The ascent of magma is difficult enough to explain differentiation and formation of calderas between 8 and 2 Ma before the inception of convergence. The change in volcanism at $2 \mathrm{Ma}$ is linked to the decrease of $\sigma_{\mathrm{Hmax}}$ and an easier ascent of magma. During this evolution, tectonic erosion was active along the Japan Trench, which may explain the westward migration of the volcanic front after $20 \mathrm{Ma}$ and the abnormal position of the 20-Ma volcanic front close to the present trench.

\section{Tectonic Implications of Reconstructions}

Although reconstruction is to be taken with caution because large uncertainties remain concerning the timing and geometry, an important consequence is the allowance of an approximate quantification of the finite motion along the major dextral shear zone that runs from Central Japan to Northern Sakhalin for about $2000 \mathrm{~km}$. The latitudinal difference between the position of Hokkaido at present and on our 25-Ma reconstruction is about $400 \mathrm{~km}$ (Fig. 19). As this offset does not take into account the motion along the Hidaka Shear Zone, it is a minimum value. However, we can speculate that once crustal thinning 
Table 1. Reconstruction poles from $25 \mathrm{Ma}$ to the present (Eurasia fixed).

\begin{tabular}{|c|c|c|c|c|}
\hline Age (Ma) & 1.8 & 15 & 20 & 25 \\
\hline & $\begin{array}{l}\text { Lat. Long. Deg. } \\
47.0 \mathrm{~N} 140.0 \mathrm{E}+0.8\end{array}$ & $\begin{array}{l}\text { Lat. Long. Deg. } \\
38.5 \mathrm{~N} 122.0 \mathrm{E}+5.0\end{array}$ & $\begin{array}{l}\text { Lat. Long. Deg. } \\
45,3 \mathrm{~N} 144.7 \mathrm{E}-12.1\end{array}$ & $\begin{array}{l}\text { Lat. Long. Deg. } \\
47.5 \mathrm{~N} 154.3 \mathrm{E}-10.4\end{array}$ \\
\hline $\begin{array}{l}\text { 1.Northeast Japan } \\
\text { 2.Okhotsk plate }\end{array}$ & $47.0 \mathrm{~N} 140.0 \mathrm{E}+0.8$ & $35.7 \mathrm{~N} 113.6 \mathrm{E}+6.0$ & $\begin{array}{l}43.5 \mathrm{~N} 144.7 \mathrm{E}-12.1 \\
10.0 \mathrm{~N} 50.0 \mathrm{E}+1.0\end{array}$ & $10.0 \mathrm{~N} 50.0 \mathrm{E}+2.0$ \\
\hline 3.Central Japan & $47.0 \mathrm{~N} 140.0 \mathrm{E}+0.8$ & $38.5 \mathrm{~N} 122.0 \mathrm{E}+5.0$ & $45.7 \mathrm{~N} 143.7 \mathrm{E}-12.6$ & $47.5 \mathrm{~N} 154.3 \mathrm{E}-10.4$ \\
\hline 4.SW Honshu & & $34.0 \mathrm{~N} 129.0 \mathrm{E}+5.0$ & $34.0 \mathrm{~N} 129.0 \mathrm{E}+15.0$ & $38.5 \mathrm{~N} 122.0 \mathrm{E}+10.0$ \\
\hline $\begin{array}{l}\text { 5.Noto Peninsula } \\
\text { 6.SW Japan }\end{array}$ & & $34.0 \mathrm{~N} 129.0 \mathrm{E}+5.0$ & $38.5 \mathrm{~N} 122.0 \mathrm{E}+10.0$ & $46.4 \mathrm{~N} 148.7 \mathrm{E}-12.2$ \\
\hline outer zones & & $34.0 \mathrm{~N} 129.0 \mathrm{E}+5.0$ & $34.0 \mathrm{~N} 129.0 \mathrm{E}+15.0$ & $38.5 \mathrm{~N} 122.0 \mathrm{E}+10.0$ \\
\hline 7. Yamato Bank & & $34.0 \mathrm{~N} 129.0 \mathrm{E}+5.0$ & $34.0 \mathrm{~N} 129.0 \mathrm{E}+6.0$ & $34.0 \mathrm{~N} 129.0 \mathrm{E}+12.0$ \\
\hline 8. Kita Yamato Bank & & $34.0 \mathrm{~N} 129.0 \mathrm{E}+5.0$ & $34.0 \mathrm{~N} 129.0 \mathrm{E}+6.0$ & $34.0 \mathrm{~N} 129.0 \mathrm{E}+10.0$ \\
\hline 9.South of Yamato & & $34.0 \mathrm{~N} 129.0 \mathrm{E}+5.0$ & $34.0 \mathrm{~N} 129.0 \mathrm{E}+6.0$ & $34.0 \mathrm{~N} 129.0 \mathrm{E}+12.0$ \\
\hline 10.Bonin Arc & $38.0 \mathrm{~N} 142.0 \mathrm{E}+3.5$ & & & \\
\hline 11.Pacific & $66.3 \mathrm{~N} 297.3 \mathrm{E}+1.7$ & & & \\
\hline 12. North Korean Ridge & & $34.0 \mathrm{~N} 129.0 \mathrm{E}+5.0$ & $34.0 \mathrm{~N} 129.0 \mathrm{E}+2.0$ & \\
\hline 13.South Korean ridge & & $34.0 \mathrm{~N} 129.0 \mathrm{E}+5.0$ & $34.0 \mathrm{~N} 129.0 \mathrm{E}+3.0$ & $34.0 \mathrm{~N} 129.0 \mathrm{E}+4.0$ \\
\hline 14.Southern margin & & & & \\
\hline of Tsuhima Basin & & $34.0 \mathrm{~N} 129.0 \mathrm{E}+5.0$ & $38.5 \mathrm{~N} 122.0 \mathrm{E}+10.0$ & $34.0 \mathrm{~N} 129.0 \mathrm{E}+7.0$ \\
\hline 15.Oki Ridge & & $34.0 \mathrm{~N} 129.0 \mathrm{E}+5.0$ & $38.5 \mathrm{~N} 122.0 \mathrm{E}+10.0$ & $34.0 \mathrm{~N} 129.0 \mathrm{E}+15.0$ \\
\hline
\end{tabular}

had begun along the eastern margin of the Japan Sea, the deformation was preferentially localized there and this domain accommodated most of the displacement. Four hundred kilometers of dextral displacement thus seems a reasonable order of magnitude. This shows that it is a major feature by both its length and its motion. When considering the major faults that took part in the deformation process of Asia during the Cenozoic, such a north-south-trending dextral fault must be taken into account as much as the contribution of the large east-west faults such as the Altyn-Tagh and Red River faults, which accommodated at a maximum twice this value in left-lateral motion (see Tapponnier et al., 1986; Jolivet et al., 1990). Only 150 to $200 \mathrm{~km}$ of dextral offset is accounted for along the Tsushima and Yangsan faults, with the difference accounted for by the clockwise rotation of Southwest Japan.

To explain the occurrence of the stress-field change and the volcanic starvation at $10-8 \mathrm{Ma}$, one must take into account all the tectonic aspects of the evolution of Japan through the Neogene. Kimura and Tamaki (1986) proposed that the Japan Sea opened as a consequence of the collision of India and Asia. Based on the analogous experiments of Cobbold and Davy (1988) and Davy and Cobbold (1988), we (Jolivet et al., 1990) reached a similar conclusion, although with a different mechanism. We also showed that a dextral transtension due to the collision was possible behind the Pacific subduction zone, provided that it is a stress-free boundary. The low coupling of a Mariana-type subduction provides this relatively stressfree boundary condition. In this context the Japan Sea opened as a right-lateral pull-apart compatible with block rotations about vertical axes deduced from paleomagnetic investigations. During this period of opening, the Philippine Sea plate was not in its present position but far southward (Seno, 1985a; Jolivet et al., 1989), and a low mechanical coupling prevailed along the whole of the Japan arc except in the north, where transpressional dextral tectonics are observed (Kimura et al., 1983; Yamagishi and Watanabe, 1986; Jolivet and Miyashita, 1985; Jolivet and Huchon, 1989) along the convergent North America-Eurasia plate boundary (Chapman and Solomon, 1976; Seno 1985b; Savostin et al., 1983; Jolivet, 1986), which departs from the stress-free assumption. The end of the northward motion of the Philippine Sea plate took place 12 to $15 \mathrm{Ma}$, when the Bonin arc first collided with Central Japan. The subduction below Southwest Japan of the young Shikoku Basin lithosphere and of the Palau-Kyushu and Bonin ridges is far less easily explained than that of the Pacific plate. This new situation might have stopped the southward migration of the Japan arc along dextral transcurrent faults and also induced a more compressional stress field. The eastern boundary thus became less free, and the North America-Eurasia compressional deformation zone propagated southward.

\section{ACKNOWLEDGMENTS}

Thanks are due Claude Froidevaux, Dave Barnes, Jacques Charvet, Gaku Kimura, and Seiya Uyeda for critical discussion and improvement of the manuscript. This paper is INSU-DBT contribution no. 381, and Contribution du Département de Géologie de l'Ecole Normale Supérieure no. 214.

\section{REFERENCES}

Amano, K., and Sato, H., 1989. Neogene tectonics of the central part of the Northeast Honshu arc. Chishitsugaku Ronshu, 32:81-96.

Angelier, J., 1984. Tectonic analysis of faultslip data sets. J. Geophys. Res., 89:5835-5848.

Bott, M. H. P., Waghorn, G. D., and Whittaker, A., 1989. Plate boundary forces at subduction zones and trench-arc compression. Tectonophysics, 170:1-15.

Cadet, J. P., and Fujioka, K., 1980. Neogene volcanic ashes and explosive volcanism: Japan trench transect, Leg 57, Deep Sea Drilling Project. In von Huene, R., Nasu, N., et al., Init. Repts. DSDP, 56, 57 (Pt. 2): Washington (U.S. Govt. Printing Office), 1027-1041.

Cadet, J. P., Kobayashi, K., Lallemand, S., Jolivet, L., Aubouin, J., Boulègue, J., Dubois, J., Hotta, H., Ishii, T., Konishi, T., Niitsuma, N., and Shimamura, H., 1987. Deep scientific dives in the Japan and Kuril trenches. Earth Planet. Sci. Lett., 83:313-328.

Chamot-Rooke, N., Renard, V., and Le Pichon, X., 1987. Magnetic anomalies in the Shikoku Basin: a new interpretation. Earth Planet. Sci. Lett., 83:214-223.

Chapman, M. C., and Solomon, S. C., 1976. North American-Eurasian plate boundary in northeast Asia. J. Geophys. Res., 81:921-930.

Charvet, J., Faure, M., Fabbri, O., Cluzel, D., and Lapierre, H., 1990. Accretion and collision during East-Asiatic margin building - a new insight on the peri-Pacific orogenies. In Howell, D. G., and Wong, F. L. (Eds.), Terrane Analysis of China and the Pacific Rim. Circum-Pac. Counc. Energy Miner. Resour., Earth Sci. Ser., 13:161-189.

Chen, W. P., and Nabelek, J., 1988. Seismogenic strike-slip faulting and the development of the North China basin. Tectonics, 7:975-989.

Cloething, S., McQueen, H., and Lambeck, K., 1985. On a tectonic mechanism for regional sealevel variations. Earth Planet. Sci. Lett., 75:157-166.

Cobbold, P. R., and Davy, P., 1988. Indentation tectonics in nature and experiments, 2: Central Asia. Bull. Geol. Inst. Upsalla, 14:143-162.

Davy, P., and Cobbold, P. R., 1988. Indentation tectonics in nature and experiments. Experiments scaled for gravity. Bull. Geol. Inst. Upsalla, 14:129-141.

Evarts, R. C., Ashley, R. P., and Smith, J. G., 1987. Geology of the Mount St. Helens area: record of discontinuous volcanic and plutonic activity in the Cascade arc of Southern Washington. J. Geophys. Res., 92:10155-10169.

Fabbri, O., Charvet, J., and Faure, M., 1988. Sur la déformation associée à la rotation de Kyushu (Japon SW) au Miocène Moyen. C. R. Acad. Sci. Ser. 2, 304:1207-1212. 
Froidevaux, C., and Isacks, B. L., 1984. The mechanical state of the lithosphere in the Altiplano-Puna segment of the Andes. Earth Planet. Sci. Lett., 71:305-314.

Froidevaux, C., Uyeda, S., and Uyeshima, M., 1988. Island arc tectonics. Tectonophysics, 148:1-9.

Fujioka, K., 1986. Synthesis of Neogene explosive volcanism of the Tohoku arc, deduced from the marine tephra drilled around the Japan trench region, Deep Sea Drilling Project Legs 56, 57, and 87B. In Kagami, H., Karig, D. E., and Colbourn, W. C., et al., Init. Repts. DSDP, 87: Washington (U.S. Govt. Printing Office), 703-721.

Fujioka, K., Cadet, J. P., and Morin, J. C., 1986. Volcanic ash at Site 584, Japan Trench. In Kagami, H., Karig, D. E., and Colbourn, W. C., et al., Init. Repts. DSDP, 87: Washington (U.S. Govt. Printing Office), 681-694.

Fukao, Y., and Furumoto, M., 1975. Mechanisms of large earthquakes along the eastern margin of the Japan sea. Tectonophysics, 25:247-266.

Gnibidenko, H., 1979. The tectonics of the Japan Sea. Mar. Geol., 32:71-87.

Hayashida, A., 1986. Timing of rotational motion of Southwest Japan inferred from paleomagnetism of the Setouchi Miocene series. J. Geomagn. Geoelectr., 38:295-310.

Hayashida, A., Fukui, T., and Torii, M., 1991. Paleomagnetism of the early Miocene Kano Group in Southwest Japan and its implication for the opening of the Japan Sea. Geophys. Res. Lett., 18:1095-1098.

Hirata, N., Kinoshita, H., Suyehiro, K., Suyemasu, M., Matsuda, N., Ouchi, T., Katao, H., Koresawa, S., and Nagumo, S., 1987. Report on DELP 1985 Cruises in the Japan Sea. Part II: seismic refraction experiment conducted in the Yamato Basin, Southeast Japan Sea. Bull. Earthq. Res. Inst. Univ. Tokyo, 62:347-365.

Hirata, N., Tokuyama, H., and Chung, T. W., 1989. An anomalously thick layering of the crust of the Yamato Basin, Southeastern Sea of Japan, the final stage of back-arc spreading. Tectonophysics, 165:303-314.

Huchon, P., 1985. Géodynamique de la zone de collision d'Izu et du point triple du Japon Central [Thèse de Doctorat]. Univ. Pierre et Marie Curie, Paris. , 1986. Comment on "Kinematics of the Philippine Sea plate" by B. Ranken, R. K. Cardwell and D. E. Karig. Tectonics, 5:165-168.

Iijima, A., Tada, R., and Watanabe, Y., 1988. Development of Neogene sedimentary basins in the northeastern Honshu arc with emphasis on Miocene siliceous deposits. J. Fac. Sci. Tokyo Univ., 21:417-446.

Ingle, J. C., Jr., Suyehiro, K., von Breymann, M. T., et al., 1990. Proc. ODP, Init. Repts., 128: College Station, TX (Ocean Drilling Program).

Isezaki, N., and Uyeda, S., 1973. Geomagnetic anomaly pattern of the Japan Sea. Mar. Geophys. Res., 2:51-59.

Ishikawa, N., and Torii, M., 1988. Counter-clockwise rotation of the Tsushima and the Goto islands, southwestern margin of the Japan Sea: evidence from paleomagnetism. Tectonics of Eastern Asia and Western Pacific Continental Margin, 1988 DELP Tokyo Int. Symp.

Ito, T., Utada, M., and Okuyama, T., 1989. Mio-Pliocene calderas in the backbone region in Northeast Japan. Chishitsugaku Ronshu, 32:409-429.

Jolivet, L., 1986. America-Eurasia plate boundary in eastern Asia and the opening of marginal basins. Earth Planet. Sci. Lett., 81:282-288.

Jolivet, L., Davy, P., and Cobbold, P., 1990. Right-lateral shear along the northwest Pacific margin and the India-Eurasia collision. Tectonics, 6:1409-1414.

Jolivet, L., and Huchon, P., 1989. Crustal scale strike-slip deformation in Hokkaido, Northeast Japan. J. Struct. Geol., 11:509-522.

Jolivet, L., Huchon, P., Brun, J. P., Chamot-Rooke, N., Le Pichon, X., and Thomas, J. C., 1991. Arc deformation and marginal basin opening, Japan Sea as a case study. J. Geophys. Res., 96:4367-4384.

Jolivet, L., Huchon, P., and Rangin, C., 1989. Tectonic setting of Western Pacific marginal basins. Tectonophysics, 160:23-47.

Jolivet, L., and Miyashita, S., 1985. The Hidaka Shear Zone (Hokkaido, Japan): genesis during a right-lateral strike-slip movement. Tectonics, 4:289-302.

Jun, M. S., 1990. Source parameters of shallow intraplate earthquakes in and around the Korean peninsula and their tectonic implication. Acta Universitatis Upsaliensis, Comprehensive Summaries of Uppsala Dissertations from the Faculty of Science, 285.

Kanaori, Y., 1990. Late Mesozoic-Cenozoic strike-slip and block rotation in the inner belt of Southwest Japan. Tectonophysics, 177:381-399.

Kaneoka, I., Notsu, K., Takigami, Y., Fujioka, K., and Sakai, H., 1990. Constraints on the evolution of the Japan Sea based on ${ }^{39} \mathrm{Ar}-{ }^{40} \mathrm{Ar}$ ages and $\mathrm{Sr}$ isotopic ratios for volcanic rocks of the Yamato seamount chain in the Japan Sea. Earth Planet. Sci. Lett., 97:211-225.

Katao, H., 1988. Seismic structure and formation of the Yamato Basin. Bull. Earthq. Res. Inst. Univ. Tokyo, 63:51-86.
Kennett, J.P., McBirney, A. R., and Thunell, R. C., 1977. Episodes of Cenozoic volcanism in the circum-Pacific region. J. Volcanol. Geotherm. Res. 2:145-163.

Kimura, G., 1986. Oblique subduction and collision, forearc tectonics of the Kuril arc. Geology, 14:404 407.

Kimura, G., Miyashita, S., and Miyasaka, S., 1983. Collision tectonics in Hokkaido and Sakhalin. In Hashimoto, M., and Uyeda, S. (Eds.), Accretion Tectonics in the Circum Pacific Region: Tokyo (Terra Sci. Publ.), 117-128.

Kimura, G., and Tamaki, K., 1986. Collision, rotation and back arc spreading: the case of the Okhotsk and Japan seas. Tectonics, 5:389-401.

Kobayashi, K., Tamaki, K., Nakanishi, M., Isezaki, N., and Sayanagi, K., 1986. Complex pseudofault pattern of the Japan Sea: results of detailed geomagnetic survey. Eos, 67:1227.

Koizumi, I., 1988. Early Miocene proto-Japan Sea. J. Paleontol. Soc. Korea, $4: 6-20$.

Lallemand, S., and Jolivet, L., 1985. Japan Sea: a pull apart basin. Earth Planet. Sci. Lett., 76:375-389.

Lallemand, S., Chamot-Rooke, N., Le Pichon, X., and Rangin, C., 1989 Zenisu Ridge: a deep intra-oceanic thrust related to subduction off Southwest Japan. Tectonophysics, 160:151-174.

Le Pichon, X., liyama, J. T., Chamley, H., Charvet, J., Faure, M., Fujimoto, H., Furuta, T., Ida, Y., Kagami, H., Lallemant, S., Leggett, J., Murata, A., Okada, H., Rangin, C., Renard, V., Taira, A., and Tokuyama, H., 1987. Nankai trough and the fossil Shikoku ridge: results of Box 6 Kaiko survey. Earth Planet. Sci. Lett., 83:186-198.

Ludwig, W. J., Murauchi, S., and Houtz, R. E., 1975. Sediments and structure of the Japan Sea. Geol. Soc. Am. Bull., 86:651-664.

Miyashita, S., Tsuchiya, N., Watanabe, Y., Ishii, J., Yamazaki, T., Sagayama, T., Izu, S., and Iwashita, M., 1987. Basaltic pillow lavas dredged from the Kaiyo-Kaizan, northeast margin of the Japan Sea. Bull. Coll. Arts Sci. Sapporo, Tokai Univ.

Murata, A., 1987. Conical folds in the Hitoyoshi bending, South Kyushu formed by the clockwise rotation of the Southwest Japan arc. Chishitsugaku Zasshi, 93:91-105.

Nakamura, K., 1977. Volcanoes as possible indicators of tectonic stress orientation-principle and proposal. J. Volcanol. Geotherm. Res., 2:1-16,

, 1983. Possible nascent trench along the eastern Japan sea as the convergent boundary between Eurasia and North American plates. Bull. Earthquake Res. Inst. Univ. Tokyo, 58:721-732. (In Japanese)

Nakamura, K., and Uyeda, S., 1980. Stress gradient in back arc regions and plate subduction. J. Geophys. Res., 85:6419-6428.

Ogawa, Y., 1983. Mineoka ophiolite belt in the Izu fore-arc area-Neogene accretion of oceanic and island arc assemblages in the northeastern corner of the Philippine Sea Plate. In Hashimoto, M., and Uyeda, S. (Eds.), Accretion Tectonics in the Circum Pacific Regions: Tokyo (Terra Sci. Publ.), 245-260.

Ohguchi, T., Yoshida, T., and Okami, K., 1989. Historical change of the Neogene and Quaternary volcanic,field in the Northeast Honshu arc. Chishitsugaku Ronshu, 32:431-455.

Otofuji, Y., Itaya, T., and Matsuda, T., 1991. Rapid rotation of southwest Japan-paleomagnetism and $\mathrm{K}-\mathrm{Ar}$ ages of Miocene volcanic rocks of southwest Japan. Geophys. J. Int., 105:397-405.

Otofuji, Y., and Matsuda, T., 1983. Paleomagnetic evidence for the clockwise rotation of Southwest Japan. Earth Planet. Sci. Lett., 62:349-359.

1984. Timing of rotational motion of Southwest Japan inferred from paleomagnetism. Earth Planet. Sci. Lett., 70:373-382.

, 1987. Amount of clockwise rotation of Southwest Japan-fan shape opening of the southwestern part of the Japan Sea. Earth Planet. Sci. Lett., 85:289-301.

Otofuji, Y., Matsuda, T., and Nohda, S., 1985. Paleomagnetic evidences for the Miocene counter clockwise rotation of northeast Japan-rifting process of the Japan arc. Earth Planet. Sci. Lett., 75:265-277.

Otsuki, K., 1985. Plate tectonics of eastern Asia in the light of fault system. Sci. Rep., Tohoku Univ., Ser. 2, 55:141-251.

1989. Reconstruction of Neogene tectonic stress field of Northeast Honshu arc from metalliferous veins. Chishitsugaku Ronshu, 32:281-304.

1990. Neogene tectonic stress field of northeast Honshu arc and implications for boundary conditions. Tectonophysics, 181:151-164.

Ranken, B., Cardwell, R. K., and Karig, D. E., 1984. Kinematics of the Philippine sea plate. Tectonics, 3:555-575.

Reches, Z., and Fink, J., 1988. The mechanism of intrusion of the Inyo dike, Long Valley caldera, California. J. Geophys. Res., 93:4321-4334. 
Rozhdestvenskiy, V. S., 1982. The role of wrench faults in the structure of Sakhalin. Geotectonics, 16:323-332.

V. S., 1986. Evolution of the Sakhalin fold system. Tectonophysics, 127:331-339.

Sakai, H., and Nishi, H., 1990. Geologic age of the Taishi Group and the Katsumoto formation in the Tsushima and Kii islands, off northwest Kyushu on the basis of planktonic foraminifers. Chishitsugaku Zasshi, 96:389-392.

Savostin, L., Zonenshain, L., and Baranov, B., 1983. Geology and plate tectonics of the Sea of Okhotsk. In Hilde, T.W.C., and Uyeda, S., Geodynamics of the Western Pacific and Indonesian Region. Am. Geophys. Union, Geodyn. Ser., 11:343-354.

Seno, T., 1977. The instantaneous rotation vector of the Philippine sea plate relative to the Eurasian plate. Tectonophysics, 42:209-226.

1985a. Is Northern Honshu a microplate? Tectonophysics, 115:177-196.

$-1985 \mathrm{~b}$. Age of subducting lithosphere and back arc basin formation in the western Pacific since the middle Tertiary. In Nasu, N., Kobayashi, K., Uyeda, S., Kushiro, I., and Kagami, H. (Eds.), Formation of Active Ocean Margins: Tokyo (Terra Sci. Publ.), 469-481.

Sillitoe, R. H., 1977. Metallogeny of an Andean type continental margin in South Korea: implications for opening of the Japan Sea. In Talwani, M., and Pitman, W. C., III (Eds.), Island Arcs, Deep Sea Trenches and Back Arc Basins. Am. Geophys. Union, Maurice Ewing Ser., 1:303-310.

Soh, W., Pickering, K. T., Taira, A., and Tokuyama, H., 1991. Basin evolution in the arc-arc Izu collision zone, Mio-Pliocene Miura Group, central Japan. J. Geol. Soc. London, 148:317-330.

Sugi, N., Chinzei, K., and Uyeda, S., 1983. Vertical crustal movements of northeast Japan since middle Miocene. In Hilde, T.W.C., and Uyeda, S., Geodynamics of the Western Pacific and Indonesian Region. Am. Geophys. Union, Geodyn. Ser., 1:317-329.

Sugimura, A., Matsuda, T., Chinzei, K., and Nakamura, K., 1963. Quantitative distribution of late Cenozoic volcanic material in Japan. Bull. Volcanol., 26:125-140.

Suzuki, K., 1989. On the late Cenozoic history in the southern part of northeast Honshu in Japan. Chishitsugaku Ronshu, 32:97-112.

Taira, A., Tokuyama, H., and Soh, W., 1989. Accretion tectonics and evolution of Japan. In Ben-Avraham, Z. (Ed.), The Evolution of the Pacific Ocean Margin: Oxford (Oxford Univ. Press), 100-123.

Takahashi, K., and Hayashi, M., 1985. Fission track ages of igneous rocks from Tsushima islands (I). Bull. Fac. Lib. Arts, Nagasaki Univ, Nat. Sci., 25:9-19.

Takeuchi, A., 1985. On the episodic vicissitude of tectonic stress field of the Cenozoic northeast Honshu arc, Japan. In Nasu, N., Kobayashi, K., Uyeda, S., Kushiro, I., and Kagami, H. (Eds.), Formation of Active Ocean Margins: Tokyo (Terra Sci. Publ.), 443-468.

Tamaki, K., 1985. Two modes of back arc spreading. Geology, 13:475-478. , 1986. Age estimation of the Japan sea on the basis of stratigraphy, basement depth and heat flow data. J. Geomagn. Geoelectr., 38:427-446. , 1988. Geological structure of the Japan sea and its tectonic implications. Chishitsu Chosasho Geppo, 39:269-365.
Tamaki, K., and Honza, E., 1985. Incipient subduction and obduction along the eastern margin of the Japan Sea. Tectonophysics, 119:381-406.

Tamaki, K., and Kobayashi, K., 1988. Geomagnetic anomaly lineation in the Japan Sea. Mar. Sci. Mon., 20:705-710. (In Japanese)

Tamaki, K., Pisciotto, K., and Allan, J., 1990. Proc. ODP, Init. Repts., 127: College Station, TX (Ocean Drilling Program).

Tapponnier, P., Peltzer, G., and Armijo, R., 1986. On the mechanics of the collision between India and Asia. In Coward, M. P., and Ries, A. C. (Eds.), Collision Tectonics. Geol. Soc. Am.-Spec. Publ., 19:115-157.

Tatsumi, Y., Otofuji, Y. I., Matsuda, T., and Nohda, S., 1989. Opening of the Sea of Japan back-arc basin by asthenospheric injection. Tectonophysics, 166:317-329.

Taylor, B., Fujioka K., et al., 1990. Proc. ODP, Init. Repts., 126: College Station, TX (Ocean Drilling Program).

Tokuyama, H., Suyemasu, M., Tamaki, K., Nishiyama, E., Kuramoto, S., Suyehiro, K., Kinoshita, H., and Taira, A., 1987. Report on DELP cruises in the Japan Sea, Part III: seismic reflection studies in the Yamato Basin and the Yamato Rise area. Bull. Earthq. Res. Inst., Univ. Tokyo, 62:367-390.

Tosha, T., and Hamano, Y., 1988. Paleomagnetism of Tertiary rocks from the Oga peninsula and the rotation of northeast Japan. Tectonics, 7:653-662.

Tsuchiya, N., 1989. Submarine basalt volcanism of Miocene Aosawa formation in the Akita-Yamagata oil filled basin, back-arc region of northeast Japan. Chishitsugaku Ronshu, 32:399-408.

1990. Middle Miocene back-arc rift magmatism of basalt in the Northeast Japan arc. Chishitsu Chosasho Geppo, 41:473-505.

Usuta, M., 1989. Geotectonic history of the southern part of Akita prefecture, Northeast Japan. Chishitsugaku Ronshu, 32:57-80.

Uyeda, S., and Kanamori, H., 1979. Backarc opening and the mode of subduction. J. Geophys. Res., 84:1049-1061.

von Huene, R., and Cullotta, R., 1989. Tectonic erosion of the front of the Japan trench convergent margin. Tectonophysics, 160:75-90.

von Huene, R., and Lallemand, S., 1990. Tectonic erosion of the Japan and Peru convergent margins. Geol. Soc. Am. Bull., 102:704-720.

Weaver, C. S., Grant, W. C., and Shemeta, J. E., 1987. Local crustal extension at Mount St. Helens, Washington. J. Geophys. Res., 92:10170-10178.

Yahata, M., 1989. Cenozoic system and its geotectonic features of the northern part of southwest Hokkaido, Japan. Chishitsugaku Ronshu, 32:7-28.

Yamagishi, H., and Watanabe, Y., 1986. Change of stress field of late Cenozoic in Southwest Hokkaido, Japan: investigation of geologic faults, dykes, ore veins and active faults. Monogr. Geol. Collabor. Jpn., 31:321-332.

Yamaji, A., 1989. Geology of Atsumi area and early Miocene rifting in the Uetsu district, northeast Japan. Chishitsugaku Ronshu, 32:305-320.

, 1990. Rapid intra-arc rifting in Miocene northeast Japan. Tectonics, 9:365-378.

Date of initial receipt: 18 March 1991

Date of acceptance: 12 November 1991

Ms 127/128B-239 

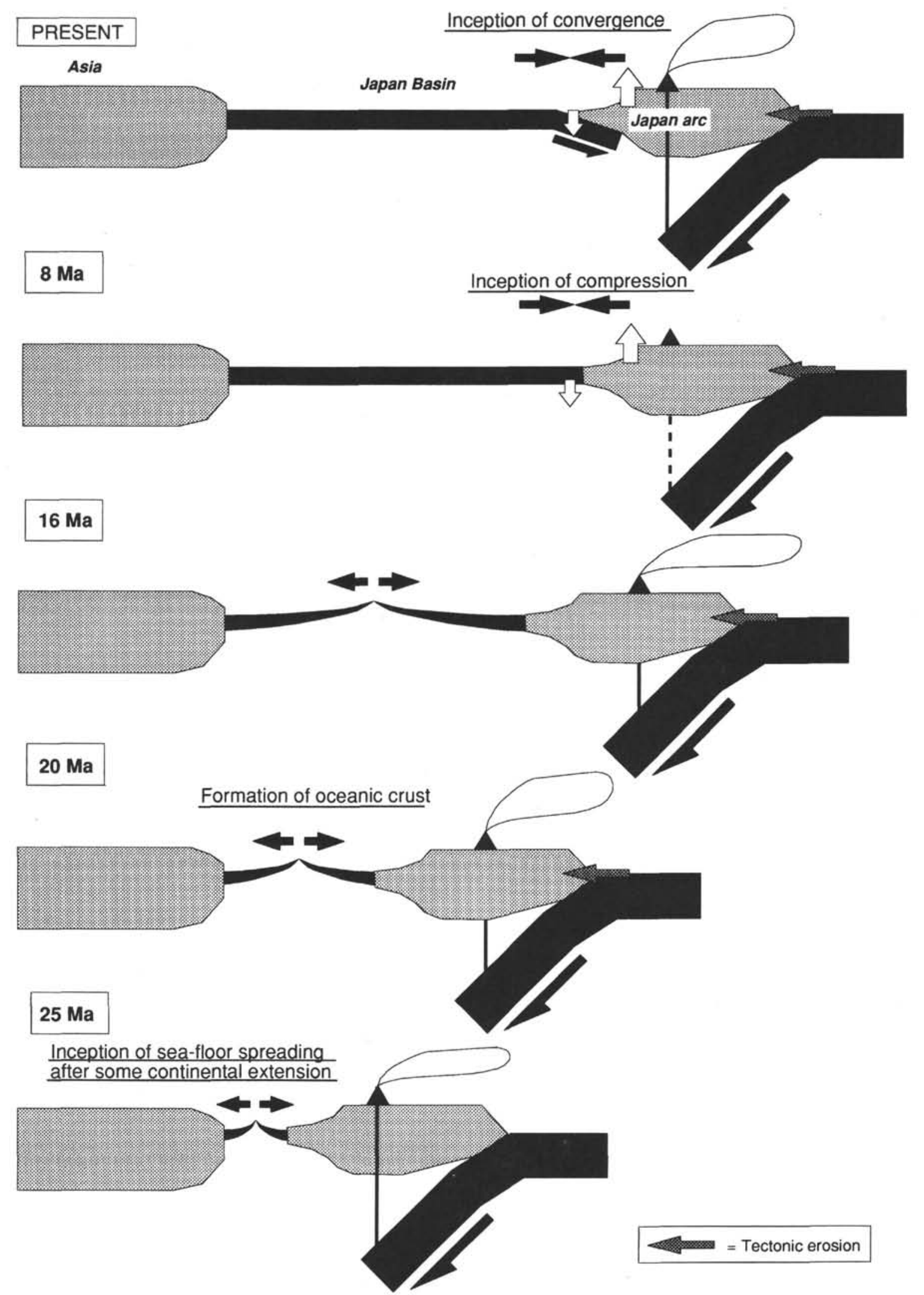

Figure 17. Cross section of the evolution of the Japan Sea and Japan arc from 25 Ma to the present. Left: Northeast Japan. Right: Southwest Japan. 

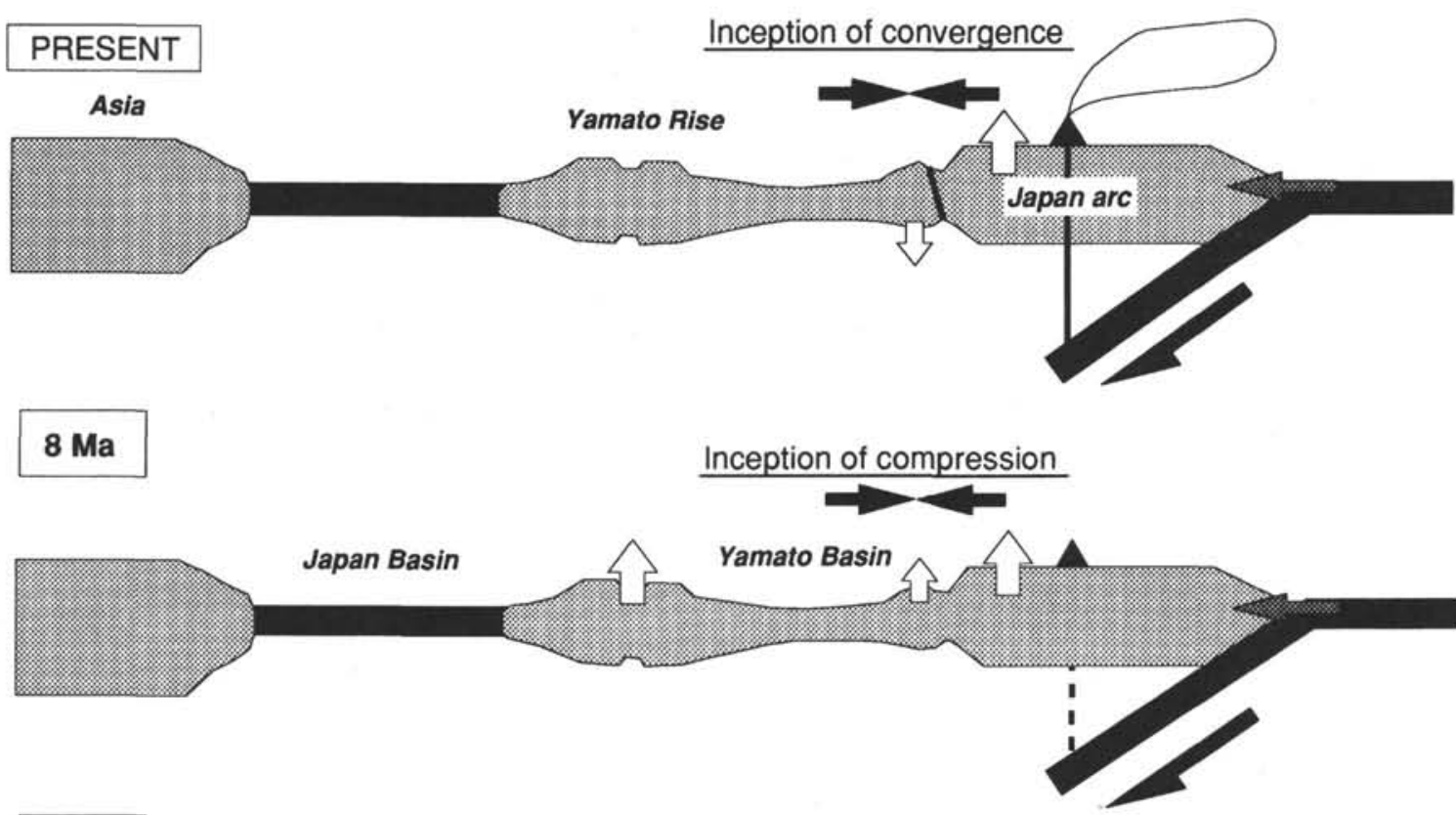

$16 \mathrm{Ma}$

Formation of oceanic crust
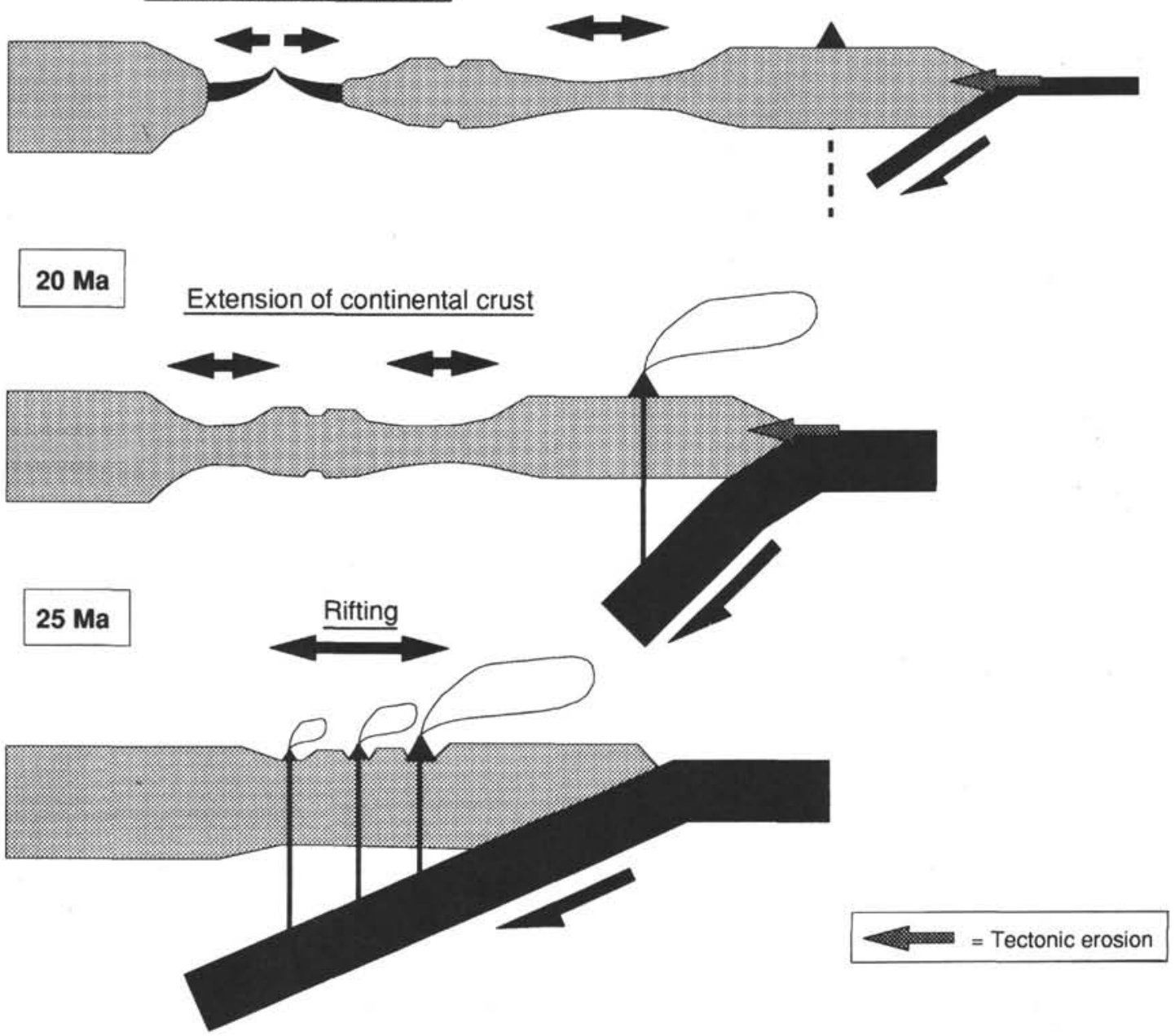

Figure 17 (continued). 


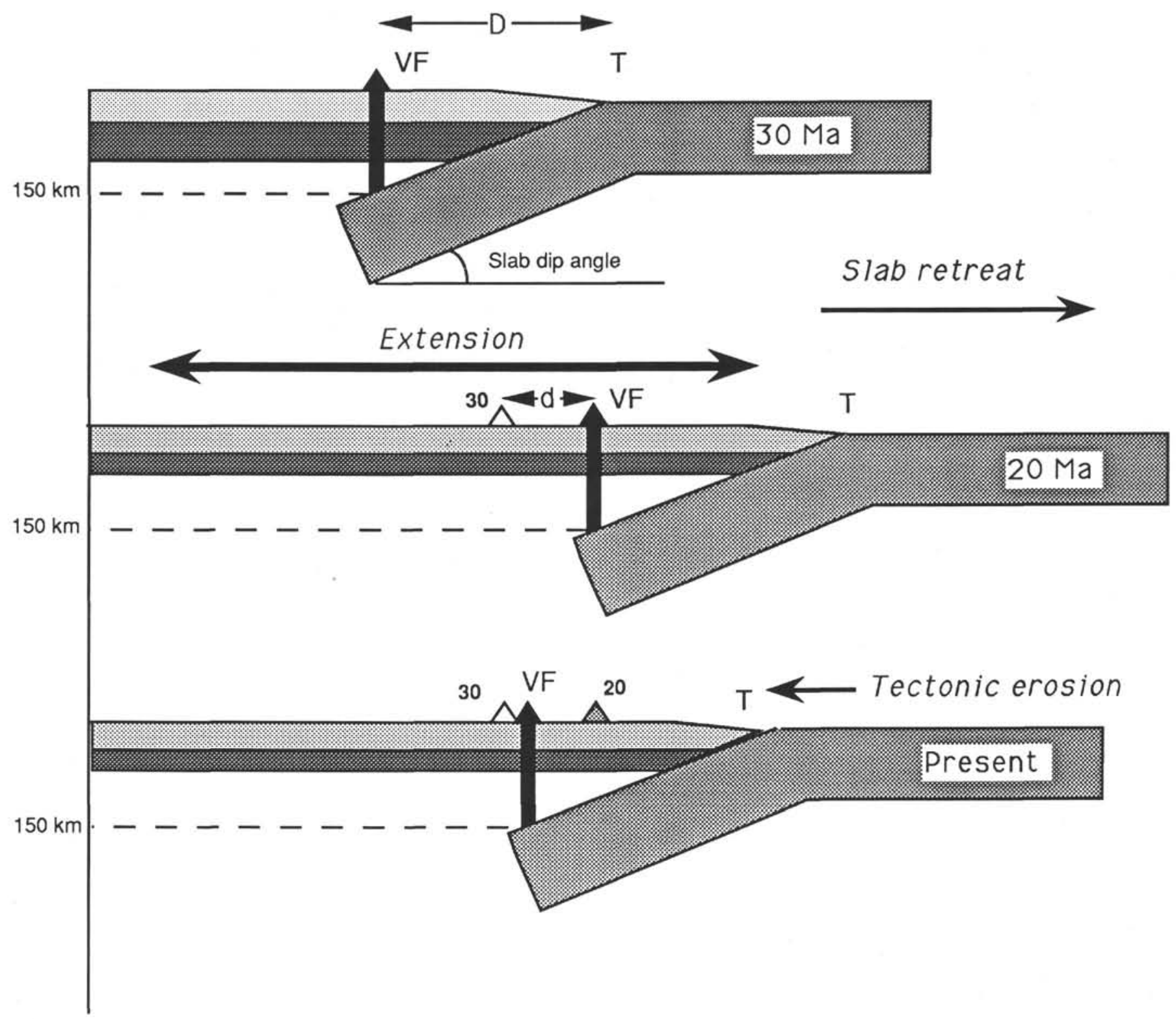

Figure 18. Migration of the volcanic front from $30 \mathrm{Ma}$ to the present. $\mathrm{VF}=$ volcanic front, $\mathrm{T}=$ trench, $\mathrm{D}=$ distance between volcanic front and trench, $\mathrm{d}=$ distance between the 20- and 30-Ma volcanic fronts. During the rifting period, homogeneous stretching of the arc lithosphere is assumed. D is kept constant through time because the slab geometry is supposedly constant. 


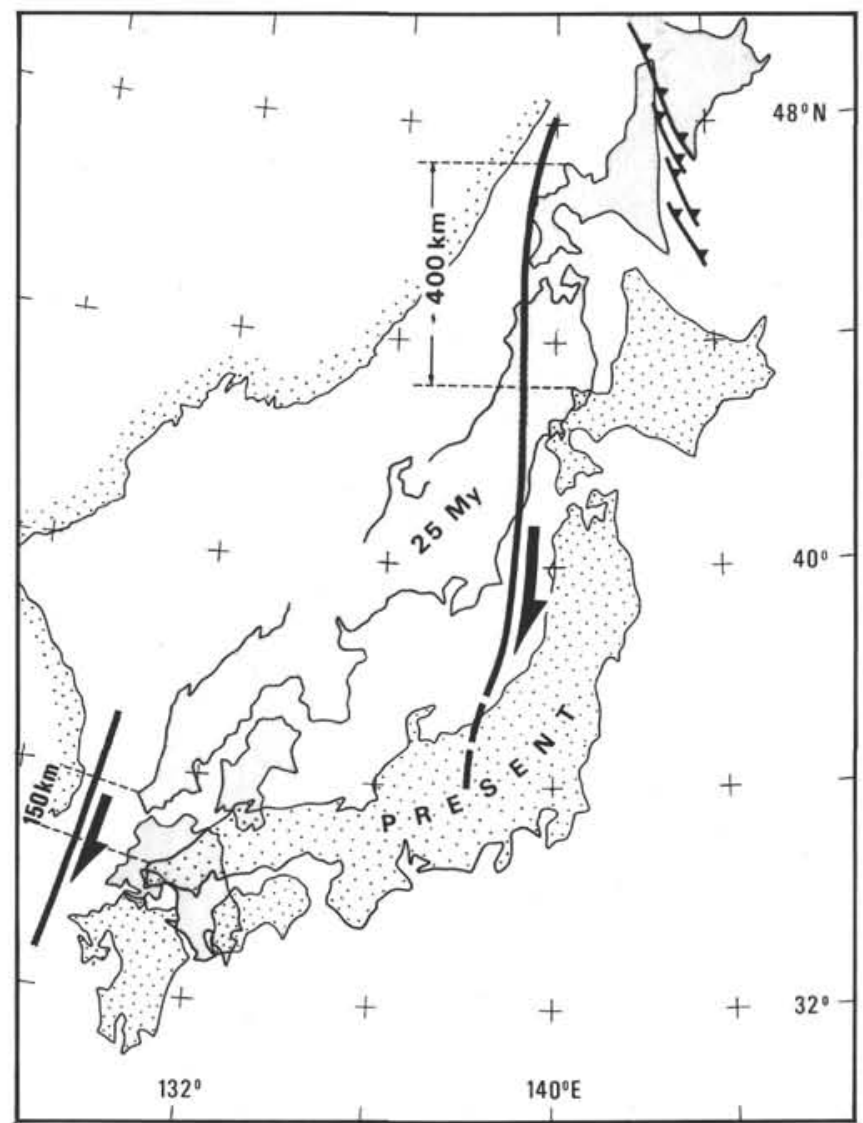

Figure 19. Comparison of the position of the Japan arc in the present and the early Miocene, with estimation of the relative displacement along the major strike-slip faults. 